\title{
Spatiotemporal Analysis of Size and Equity in Ownership Dynamics of Agricultural Landholdings in India Vis-à-Vis the World
}

\author{
K. Kareemulla *, Pandian Krishnan*(D), S. Ravichandran, B. Ganesh Kumar (D), Sweety Sharma \\ and Ramachandra Bhatta
}

check for updates

Citation: Kareemulla, K.; Krishnan, P.; Ravichandran, S.; Kumar, B.G.; Sharma, S.; Bhatta, R. Spatiotemporal Analysis of Size and Equity in Ownership Dynamics of Agricultural Landholdings in India Vis-à-Vis the World. Sustainability 2021, 13, 10225. https://doi.org/10.3390/su131810225

Academic Editors: Bazyli Czyżewski, Sebastian Stępień and

Łukasz Kryszak

Received: 27 June 2021

Accepted: 12 August 2021

Published: 13 September 2021

Publisher's Note: MDPI stays neutral with regard to jurisdictional claims in published maps and institutional affiliations.

Copyright: (c) 2021 by the authors Licensee MDPI, Basel, Switzerland. This article is an open access article distributed under the terms and conditions of the Creative Commons Attribution (CC BY) license (https:/ / creativecommons.org/licenses/by/ $4.0 /)$.
Indian Council of Agricultural Research (ICAR), National Academy of Agricultural Research Management (NAARM), Hyderabad 500030, India; ravichandran@naarm.org.in (S.R.); drgankum@yahoo.com (B.G.K.); ssharma6411@gmail.com (S.S.); rcbhat@gmail.com (R.B.)

* Correspondence: kalakareem@gmail.com (K.K.); krishnanars@yahoo.com (P.K.)
Abstract: The increasing threat to sustainable agriculture is a major concern of planners worldwide. Human population growth together with increasing food requirements and competition for land use is leading to land scarcity for agricultural purposes. Farm size influences the extent of the adoption of mechanization and modern methods of farm management practices, which in turn results in increased productivity, production efficiency and agricultural income. We studied changes in macroeconomic factors such as dependency on agriculture, growth of the sector, the pattern of landholdings and tenure rights across major agriculturally important countries, as well as the priority of agriculture for the national economy (i.e., the share of agriculture in the national income) and its relationship to changes in farm size. The data on the percentage of area under farming, population growth, size of the agricultural workforce and other social dimensions from 24 countries of different geographical sizes were analysed. We used parameters such as the extent of changes in cropland, family-owned land, the agricultural workforce and their productivity, number of holdings and their distribution, women-headed holdings and finally total and per capita agricultural income, and measured the changes over time and space. The published data from national and international sources were used to establish the relationship between farm size and farm efficiency measured through the selected parameters. The results clearly establish that the size of farm holdings had an inverse relationship with the population dependent on agriculture, share of agriculture in national income and tenure rights. Australia had the largest average agricultural landholding (3243 ha), while India and Bangladesh had the lowest (1.3 and 0.3 ha, respectively). The inequality in the distribution of farmland ownership was greater in developed countries than in developing countries. Female farmland ownership was less than $20 \%$ in most developing countries and the relationship between the number of farm households and farm outcomes was found to have weakened over time. India, a developing as well as an agriculturally important country, was subjected to detailed analysis to understand the spatiotemporal dynamics of the size, distribution and ownership patterns of agricultural landholding.

Keywords: farmland ownership; equity; agricultural work force; tenure rights; agricultural productivity

\section{Introduction}

Globally, human population growth together with increasing food requirements and competitive land use is leading to land scarcity for agriculture and other uses [1] Around 2.5 billion of the rural population are dependent on agriculture for their livelihoods. Agriculture constitutes the backbone of the economy in both developed and developing countries. Agricultural land area has increased in the world from 4.47 billion ha (1961) to 4.80 billion ha in 2017 [2]. Agricultural landholdings show a wide diversity across geographic regions [3]. Fragmented ownership of farmland is an important underlying 
cause of land degradation and is also an obstacle to sustainable land management [4]. Land ownership and operation are two distinct aspects of the same resource. Globally there is great inequality in land ownership. An analysis of land ownership data in the world for the period of 1920 to 2017 indicates that the Gini coefficient value was 0.64 for the early years of the 20th century, which indicates higher inequality in ownership, which then decreased from 1940 to 1980. However, inequality later increased, and the Gini coefficient value was 0.62 by 2017. This goes to show that the ownership is getting concentrated [5].

Agriculture is evolving gradually in its character from subsistence to a commercial enterprise and this transition is significantly guided by property rights, operational practices and farm economics. The farm economy of developing countries is characterized by disguised unemployment, scarcity of capital and sub-optimal farm size. Declining farm size is also affecting the application of modern methods of farming such as farm mechanization, reducing the scope for increasing farm yield and farm income [6,7]. A country like India, with majority of the landholdings being less than a hectare, lacks access to inputs and credit leading to poor productivity [8]. Even an average "large farm" (17 ha) in India is not as large as an average farm in countries like the USA, Canada, Brazil or Australia, where the average farm size is in the range of 70-3200 ha. Access to land and other natural resources is the key means of saving rural people from absolute poverty. In Kenya and Uganda, land markets have been shown to induce efficiency and enhance equity by transferring land from land-abundant to land-constrained households [9]. Therefore, landholding size has implications on either side, i.e., depending on the context and the level of development.

The average farm size is inversely proportional to the population and extent of total agricultural land area available in a country and thus poor countries, generally with a larger share of population dependent upon agriculture, have smaller landholdings [4]. It is believed that one of the most important requirements is to ensure property rights and access to land for productive use and thus promote long-term investments for land management and reap the benefits without constraints [10]. Positive relationships exist between household wealth and land utilization and poverty will be an impediment in successful land management [11].

The nature of agricultural land ownership or operation is driven by factors such as governance of the extent of land ownership, tenurial/leasing restrictions and revenue rates (taxes on land). The change in land ownership following the collapse of the state sector and restitution of farmland to cultivators is one of the key factors shaping contemporary land use in Central and Eastern Europe [12]. Prompted by extensive land reforms initiated by the government of India, with the active support of freedom fighters like Vinoba Bhave in the first two decades after independence, several states came out with acts to impose a land ceiling and redistribute surplus land to the landless [13]. Equity in property rights is an important strategy for increasing empowerment and economic welfare for women in developing countries, which aids their intra-household bargaining power [14].

In the light of the above, it is imperative to study and analyse the patterns and trends of the distribution of land ownership across geographical regions, gender and various social classes across major agricultural countries in the world and with special reference to India, a developing country, to draw insights on their relevance to the growth, stability and sustainability of agricultural income. This paper evaluates the impact of farm size on farm efficiency and the factors responsible for the differences in this internationally, highlighting the Indian context, and discusses the causes of higher farm productivity in countries with larger farm sizes compared to others with smaller landholdings, based on the empirical evidence. A critical evaluation of the status of agricultural landholdings in India; spatiotemporal changes in individual, family and institutional ownership; the efficiency of the agricultural workforce and equity in the number and size of land ownership across social classes and genders was made and appropriate recommendations are put forth for the improvement and sustainable management of agricultural land. 


\section{Methodology}

The spatial analysis of land ownership in India vis-à-vis other countries was undertaken to assess its concentration and distribution. Similarly, temporal analysis was undertaken to understand the dynamics of agricultural holdings and to identify the causes for their patterns. The relationship between the extent of the population dependent on agriculture (the workforce) and its productivity as measured by per capita agricultural income is an important variable for an understanding of the influence of farm size on livelihood options and strategies.

To profile the agricultural landholding pattern across the world, 24 countries were selected, representing all seven continents, based on their total geographical area and proportion of area devoted to agriculture. These countries were classified into three groups, viz., (i) large countries by geographical area $\left(>2\right.$ million $\left.\mathrm{km}^{2}\right)$, (ii) agriculturally important countries (those with $>40 \%$ of the total workforce in agriculture), and (iii) countries with a larger share of agricultural land ( $>75 \%$ ) devoted to agriculture). These country-specific agricultural landholding data were extracted from a World Bank web resource [15].

Detailed data on temporal changes in agricultural landholdings in India were obtained from the agriculture census data of the government of India [16]. Data on the share of the total geographical area devoted to agriculture, the extent of the workforce involved in agriculture and their productivity, and patterns of land ownership across gender and social classes were collected from the agricultural census data (conducted once every five years), and spatiotemporal changes in the above parameters were analysed. Data on workers by profession were extracted from the population census [17]. There are 29 states and 8 union territories in India. In the current study, the top 11 states, which together account for almost $70 \%$ of the agricultural land of the country, were chosen for state-wise comparison against selected parameters.

Gini coefficients [18] were computed to compare temporal changes in the concentration of landholdings in the selected countries and to explain the impact of such concentration. A Gini coefficient is a statistical measure of the degree of variation represented in a set of values, used especially in analysing income and assets like land inequality. An increase in the Gini coefficient suggests that land (ownership) is becoming more unevenly distributed and the opposite would imply a more equitable distribution of this natural resource [19].

The property ownership pattern was evaluated concerning gender social parity, i.e., the share of women farmers and different age classes and the extent of land operated by tenant farmers (i.e., farmers who undertake farming in land leased out from owners of such lands). The viability of farming was assessed based on the cost of cultivation, income from various farm and non-farm activities, labour wages, etc., of the farm families through tabular analysis. Growth rates in population and per capita land ownership were estimated.

A one-way ANOVA was performed to test the significance of variations among the parameters statistically. A paired ' $t$ ' test was used to test the null hypothesis that the mean score obtained between the pairs of observations was zero. The correlation coefficient was determined to examine trends and the relationship between population and per capita land ownership across the major countries. All statistical analyses were performed using the software program R [20].

\section{Results and Discussion}

\subsection{Global Status of Agriculture Landholding}

Land ownership is a key factor in creating an enabling environment that promotes agricultural productivity and sustainable growth. Secure land rights lead to increased agricultural productivity by providing incentives to invest in land and crop improvements, increasing opportunities for poor families to access financial services and government programmes, and creating the space needed for more optimal land use. 


\subsubsection{Agricultural Land}

Historically, after civilizations introduced the systematic management of land for cultivating crops and rearing livestock, agriculture became the major land use category. In the current study, where countries were classified into three categories based on geographical area, agricultural importance and extent of the area devoted to agriculture, the share of agricultural land in the total geographical area of the selected countries was found to range between 7 and $83 \%$ (Figure 1). The world average of the percentage shares of agriculture area to the total geographical area during 2016 was 37\% (Figure 2). India, the seventh-largest country in terms of geographical area, had the largest extent of its total area $(60 \%)$ devoted to agriculture, followed by other large countries like China (56\%), Argentina (54\%), the USA (48\%) and Australia (48\%). Russia, the leading country in terms of geographical area, had only $13 \%$ of its land devoted to agriculture. Among smaller countries, which have a significantly higher area devoted to agriculture ( $>70 \%)$, Uruguay ranked first with $83 \%$ of its total area devoted to agriculture, followed by Saudi Arabia $(81 \%)$, Kazakhstan $(80 \%)$ and South Africa $(80 \%)$. Ten countries account for $53 \%$ of the total agricultural area in the world (Figure 2). China, the USA and Australia are the leading countries in terms of agricultural area. Such a concentration of agricultural land among a few countries provides them a competitive edge in trade and markets.

Globally, the switch from expansion to intensification of input use, which is seen as the primary strategy for increasing crop production, has reduced the demand for land conversion by over 1 billion hectares since the early 1960s [21]. Among the countries with large geographical areas, such as in China, Brazil, India and Argentina, a significant $(p<0.05)$ increase in the extent of agricultural land has been observed over the last 55 years (Table 1). The long-term rate of growth was the highest (almost 1\% per annum) in Brazil, followed by China, placing them among the world's top five producers and exporters of agricultural products [22], which has been achieved by bringing forest and fallow lands under cultivation. In developed countries like the USA, Canada and Australia, the growth rate of agricultural land expansion was negative, yet the growth in yields and intensified agricultural practices has compensated for this loss. Further, the expansion of arable land in the whole world (155 million hectares, accounting for $11 \%$ of the world's geographical area) occurred mostly 1961-1963 and 1997-1999, and is the net result of countervailing trends, i.e., the accelerated growth rate in developing countries coupled with a marginal decline in developed nations [23].
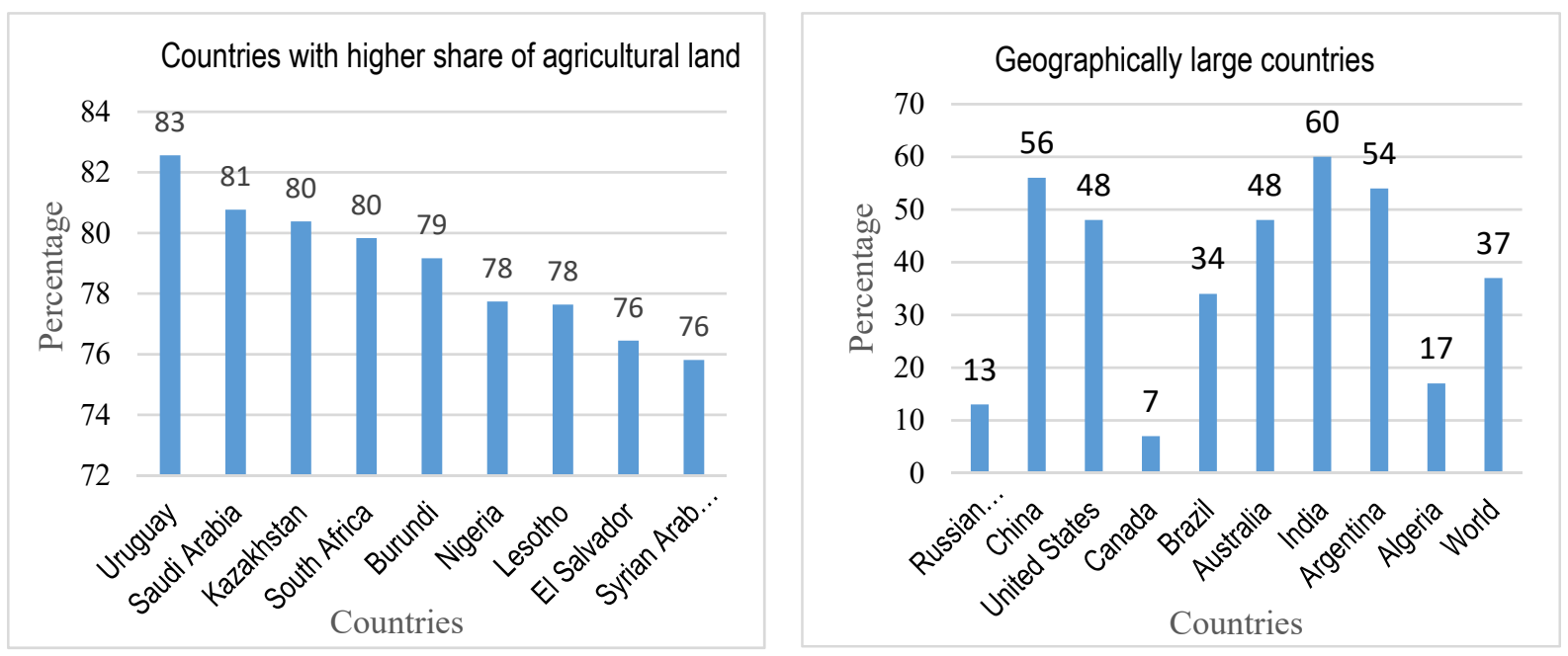

Figure 1. Agriculture area as a percentage of total geographical area. 


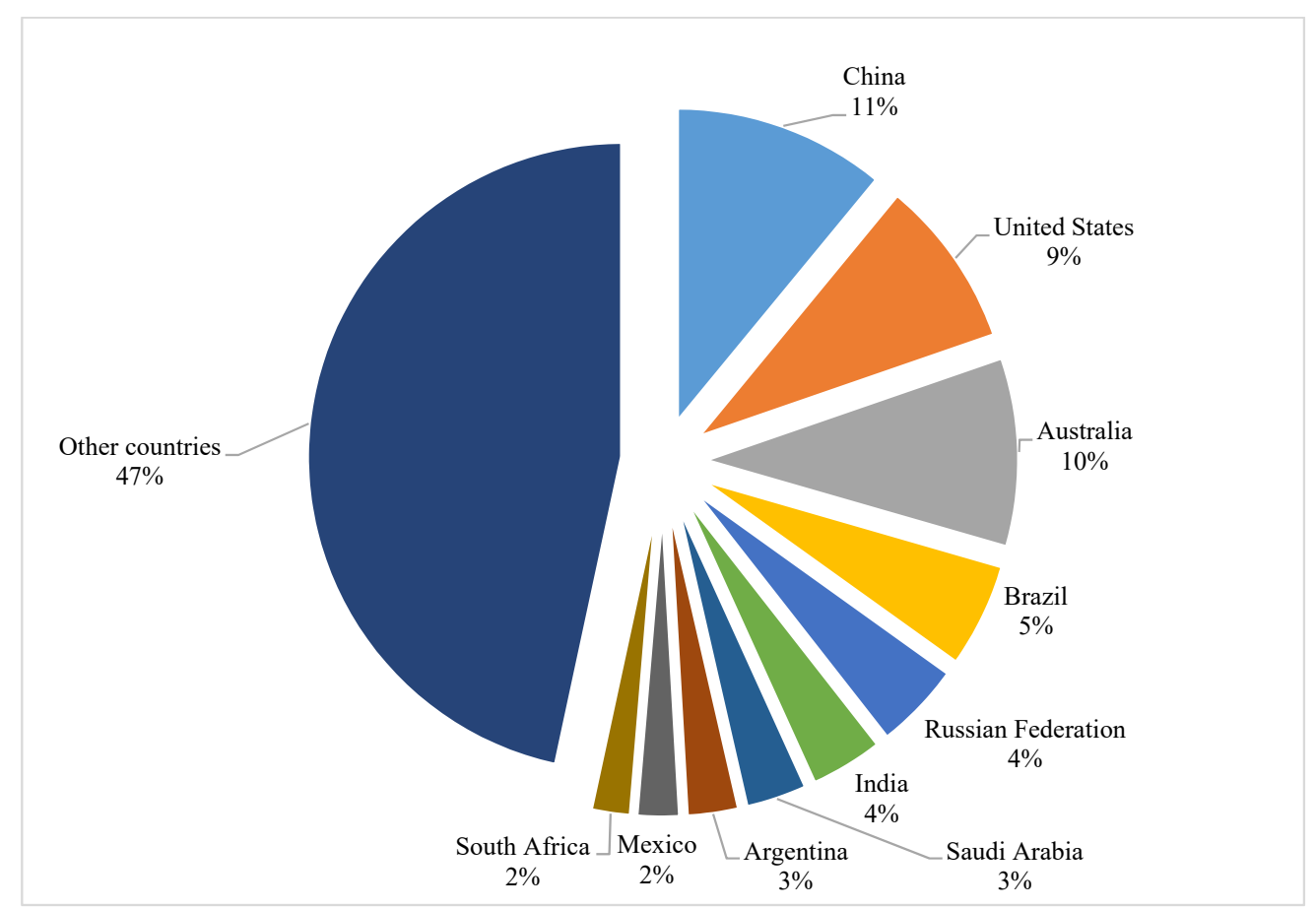

Figure 2. Distribution of agriculture area among major countries during 2016.

Table 1. Temporal variations in the agriculture area in selected countries grouped by (a) geographical area (b) agricultural importance and (c) extent of area devoted to agriculture.

\begin{tabular}{|c|c|c|c|c|c|c|}
\hline \multirow{2}{*}{ Country } & \multicolumn{3}{|c|}{ Agricultural Area $\left(\mathrm{km}^{2}\right)$} & \multicolumn{3}{|c|}{ CAGR, \% } \\
\hline & 1961 & 1991 & 2016 & 1961-2016 & 1961-1990 & 1991-2016 \\
\hline \multicolumn{7}{|c|}{ (a) Large countries by geographical area } \\
\hline China & $3,423,500$ & $5,113,790$ & $5,277,330$ & 0.85 & 1.41 & -0.01 \\
\hline United States & $4,475,090$ & $4,269,480$ & $4,058,625$ & -0.20 & -0.10 & -0.20 \\
\hline Canada & 698,250 & 677,530 & 626,710 & -0.20 & -0.20 & -0.40 \\
\hline Brazil & $1,505,310$ & $2,449,410$ & $2,835,460$ & 0.99 & 1.53 & 0.54 \\
\hline Australia & $4,615,850$ & $4,629,740$ & $3,710,780$ & -0.30 & 0.00 & -0.90 \\
\hline India & $1,749,520$ & $1,815,860$ & $1,797,210$ & 0.03 & 0.11 & -0.04 \\
\hline Argentina & $1,378,290$ & $1,276,600$ & $1,487,000$ & 0.19 & -0.20 & 0.81 \\
\hline Algeria & 454,710 & 386,220 & 413,602 & -0.20 & -0.20 & -0.40 \\
\hline \multicolumn{7}{|c|}{ (b) Agriculturally important countries } \\
\hline Bangladesh & 94,800 & 103,200 & 91,942 & -0.10 & 0.28 & -0.20 \\
\hline Egypt, Arab Rep. & 25,680 & 26,430 & 37,338 & 0.76 & -0.20 & 0.94 \\
\hline France & 345,390 & 304,849 & 287,180 & -0.30 & -0.40 & -0.30 \\
\hline Kenya & 252,000 & 268,770 & 276,300 & 0.19 & 0.20 & 0.13 \\
\hline Pakistan & 357,300 & 352,700 & 368,440 & -0.01 & 0.00 & 0.01 \\
\hline \multicolumn{7}{|c|}{ (c) Countries with a larger share devoted to agricultural land } \\
\hline Uruguay & 163,540 & 149,210 & 144,496 & -0.20 & -0.30 & -0.20 \\
\hline Saudi Arabia & 861,700 & $1,236,720$ & $1,736,190$ & 1.82 & 0.86 & 1.14 \\
\hline South Africa & $1,013,350$ & 960,050 & 968,410 & 0.02 & -0.20 & -0.02 \\
\hline Burundi & 15,750 & 21,100 & 20,330 & 0.15 & 1.11 & 0.30 \\
\hline Nigeria & 531,765 & 639,290 & 708,000 & 0.63 & -0.08 & 0.34 \\
\hline Lesotho & 25,810 & 23,230 & 23,570 & & & \\
\hline El Salvador & 12,520 & 14,280 & 15,840 & 0.49 & 0.49 & 0.44 \\
\hline Syrian Arab Republic & 149,410 & 135,120 & 139,210 & -0.06 & -0.20 & 0.09 \\
\hline World & $37,189,666$ & $40,775,831$ & $48,632,688$ & 0.62 & 0.28 & 0.24 \\
\hline
\end{tabular}


A disaggregated analysis of agricultural land area was undertaken for two time periods, viz., 1961-1990 and 1991 onwards, which correspond with the pre- and postglobalization periods, so as to assess the impact of liberalisation and globalisation on land-use changes, especially in the extent of agricultural land. In the case of almost all the larger countries, there was a reduction in the extent of agricultural land in the 25 years of the post-liberalised/globalised era, although in some countries it was not significant $(p>0.05)$. The trend was similar among the agriculturally important countries.

Almost 180 countries of the world account for $41.8 \%$ of the world's value of output from agriculture, while the agriculturally important countries, like China, India and the USA, contributed 23.9, 11.6, and 6.3\%, respectively (Figure 3). The higher agricultural output (in USD) of countries that are larger in terms of geographical area and population, like China, the USA and India (but excluding Russia), could be attributed to efficient utilization of natural resources and diversified agro-climatic situations, and also to the historical evolution of agricultural practices coupled with innovations in agricultural research. While the rapid progress of agricultural development in China could be attributed to the introduction of general and agricultural reform in 1978 [25], that of the USA is attributed to higher total factor productivity [26].

\section{World Value of Output from Agriculture: 2996 Billion US \$}

Other countries (180 countries)

Russian Federation

Turkey

Brazil

Nigeria
Indonesia

United States

India

China

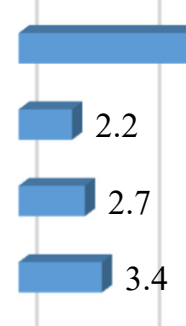

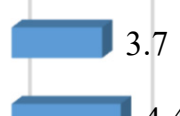

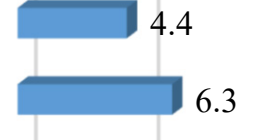

6.3
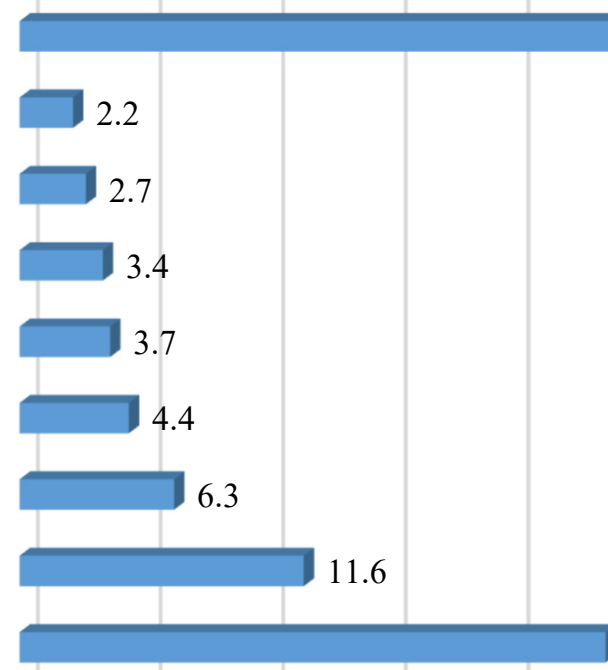

11.6

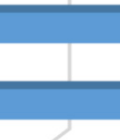

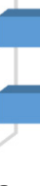

0.0
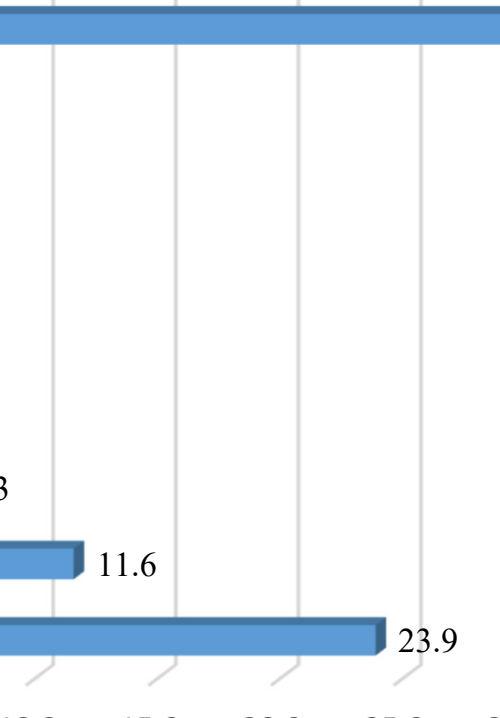

10.0

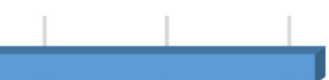

41.8

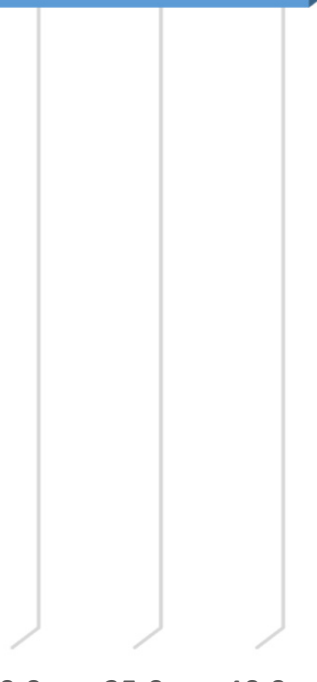

Figure 3. Percentage of total value of agriculture output-2016. (Constant USD 2010).

\subsubsection{Individual and Family Farms}

Individual and family-owned agricultural holdings are a significant feature of farming. Family farming is a means of organizing agricultural, forestry, fishery, pastoral, and aquaculture production, in which land is managed and operated by a family and is predominantly reliant on family labour including both women and men [27] and in which domestic and farming activities are intrinsically linked [2]. Farming in Asia, Africa and Europe is dominated by family farms, which comprise $97-99 \%$ of farms and cover in the range of $67-85 \%$ of the land area (Table 2). 
Table 2. Family farms across countries in 2010.

\begin{tabular}{ccc}
\hline Country & \% of Family Farms & \% Land Held \\
\hline Asia & 99 & 85 \\
Africa & 97 & 67 \\
Australia-Oceania & 78 & 2 \\
Europe & 97 & 69 \\
North America & 88 & 68 \\
South America & 82 & 18 \\
\hline
\end{tabular}

Source: Reference [2].

Countries like China, India and the USA have more than $80 \%$ of holdings in the family farms category. Brazil is reported to have around 30\% of farms owned and operated by families, and countries like Mexico and Argentina have less than $20 \%$ of agriculture holdings owned by families. It is estimated that over 500 million farms are family-owned globally [28] and they contribute $80 \%$ of the world's food production; $80 \%$ of the extremely poor are rural and mainly depend on agriculture for their livelihoods. The period 2019-2028 has been declared as the United Nations Decade of Family Farming (UNDFF) by FAO [2], to foster cross-sectoral policy, investment and innovation in family farming and to unleash the potential of family farmers as agricultural agents of change to realize sustainable food systems and help achieve the Sustainable Development Goals (SDGs).

India, the second-largest populated country and seventh largest in geographical area, is placed seventh in terms of agricultural area with 158 million ha; the world total is 4828 million ha [29]. Family holdings in India comprise over 99\% of the total farm holdings, while the rest are institutional holdings. Among the family holdings, individual holdings dominate, followed by joint family holdings (Table 3). In the last two decades (1995-1996 to 2015-2016), based on the quinquennial agriculture census data [16], the share of individual holdings has decreased while the absolute number increased (Figure 4).

Table 3. Composition of agricultural holdings in India.

\begin{tabular}{|c|c|c|c|c|c|c|c|c|}
\hline \multirow{3}{*}{ Particulars } & \multicolumn{4}{|c|}{$2015-2016$} & \multicolumn{4}{|c|}{ 1995-1996 } \\
\hline & \multicolumn{2}{|c|}{ No. of Holdings (000s) } & \multicolumn{2}{|c|}{ Area (000 ha) } & \multicolumn{2}{|c|}{ No. of Holdings (000s) } & \multicolumn{2}{|c|}{ Area (000 ha) } \\
\hline & No. & $\%$ & Ha & $\%$ & No. & $\%$ & Ha & $\%$ \\
\hline Total holdings & 146,454 & 100 & 157,817 & 100 & 115,580 & 100 & 163,355 & 100 \\
\hline (i) Family holdings & 146,190 & 99.8 & 156,277 & 99.0 & 115,366 & 99.8 & 161,935 & 99.1 \\
\hline (a) Individual family holdings & 125,466 & 85.7 & 129,247 & 82.7 & 100,581 & 87.0 & 134,905 & 82.6 \\
\hline (b) Joint family holdings & 20,724 & 14.1 & 27,030 & 17.3 & 14,785 & 12.8 & 27,030 & 16.5 \\
\hline (ii) Institutional holdings & 264 & 0.2 & 1540 & 1.0 & 214 & 0.2 & 1420 & 0.9 \\
\hline
\end{tabular}

On the other hand, the number $(14,785$ to 20,724$)$ and share (12.8 to $14.1 \%)$ of joint family holdings has increased in the corresponding period. The average holding size of farms of different categories - individual families, joint family and institutions (temples and other religious institutions) - indicates that farm size has decreased between 1995-1996 and 2015-2016 (Figure 4). In India, farm consolidation has been promoted since the 1960s as the norm, as it was consistently recognized that productivity follows a U-shaped distribution curve. Productivity seems to be highest among the smallest and largest farms. While small and large farms are comparable in terms of productivity, their methods of achieving output differ greatly. In fact, farm size predicts management practices. Large farms' ability to employ labour is often limited, which makes operators more reliant on machinery. Ironically, small farms are generally characterized by their inability to afford machinery. However, research recognizes that heavy machinery causes soil compaction, a decrease in oxygen and the suffocation of microorganisms and fungi. Further, compacted soil drains less surface water, increasing water pollution and erosion. The association between farm size and pesticide use was consistent even after statistically adjusting for soil quality, crop 
type and region, suggesting that farm size is a strong factor influencing the amount of pesticide applied.

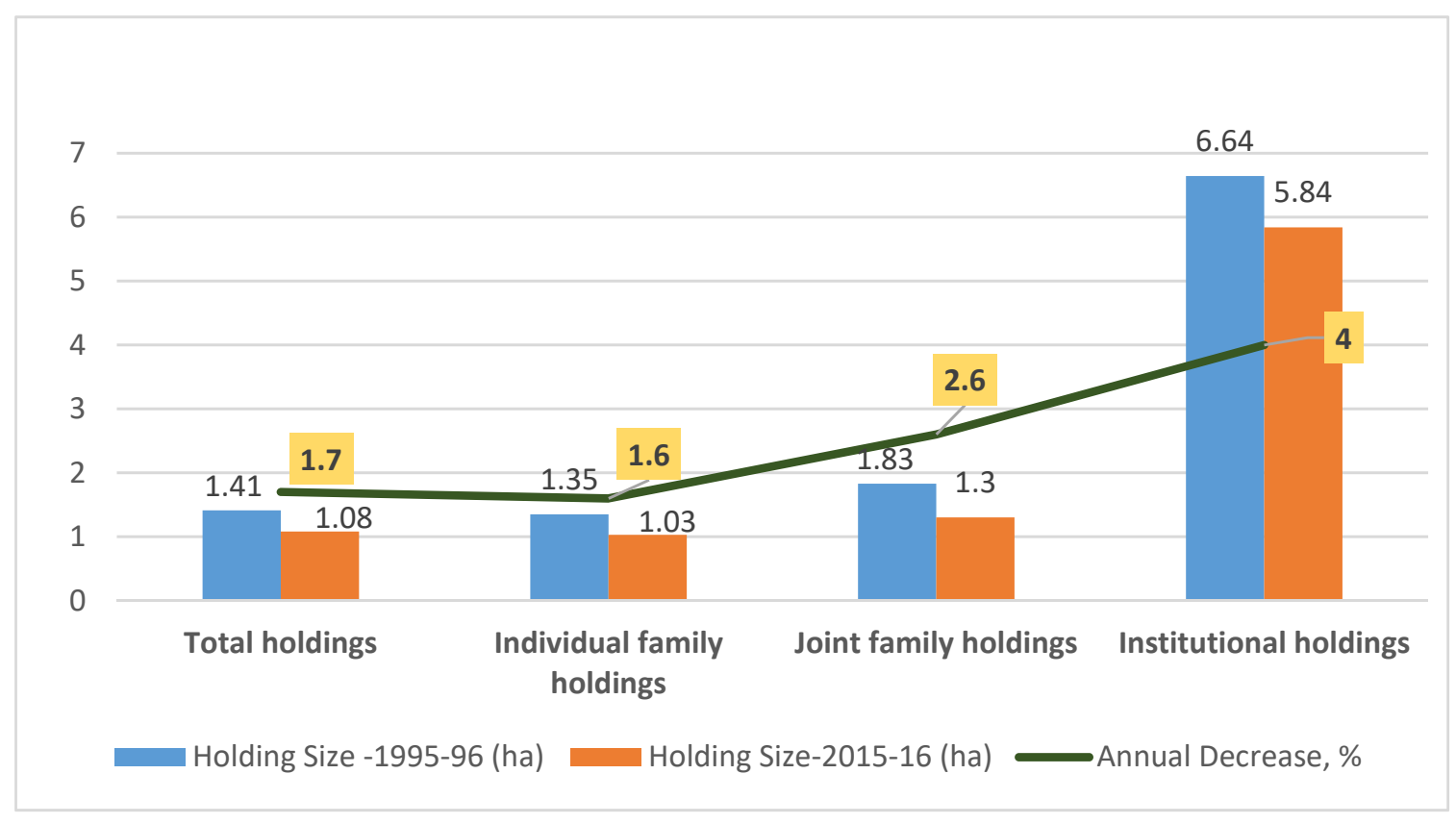

Figure 4. Average holding size by category (ha).

While small farms of economic size are considered more efficient operationally and promote social harmony in the villages better than large farms, large farms facilitate mechanization and modernization. Policies to promote large farms would weaken small farms' ability to compete and might create distress among the owners of small farms and even lead to the disposal of such small holdings. In this context, the impact of the farm laws promulgated by the government of India [30] to reform agricultural markets and facilitate the formation of farmer-producer organizations on landholdings will in the future need to be studied.

\subsubsection{The Agricultural Workforce and Its Productivity}

The value of the output from the agricultural sector and the extent of the population dependent on it signify the importance of agriculture in any country. The agricultural sector's share in both employment and output is higher in developing countries relative to developed ones; more precisely, the employment share is higher than that of output [31]. The country-wise percentage share of the agrarian workforce (Table 4) reveals that around $40 \%$ of the population in India, Pakistan and Bangladesh were dependent on agriculture during 2017. 
Table 4. Global status of the agricultural workforce and its productivity during 1996-2016.

\begin{tabular}{|c|c|c|c|c|c|}
\hline \multirow{3}{*}{ Name of the Country } & \multicolumn{5}{|c|}{ Agricultural Workforce } \\
\hline & \multicolumn{2}{|c|}{$\%$ Share of Total Workforce } & \multicolumn{3}{|c|}{ Productivity (USD at 2010 Prices) } \\
\hline & 1991 & 2017 & 1991 & 2017 & CAGR (\%) \\
\hline India & 64 & 43 & 769 & 1672 & 3.00 \\
\hline Pakistan & 47 & 42 & 1528 & 1700 & 0.40 \\
\hline Bangladesh & 70 & 39 & 408 & 991 & 3.90 \\
\hline China & 55 & 18 & 812 & 5805 & 7.90 \\
\hline Brazil & 28 & 10 & 2685 & 12,414 & 6.10 \\
\hline Russia & 10 & 7 & 8519 & 13,672 & 3.40 \\
\hline Saudi Arabia & 8 & 6 & 24,668 & 19,673 & 0.04 \\
\hline South Africa & 17 & 6 & 4224 & 11,544 & 6.90 \\
\hline Australia & 5 & 3 & 36,043 & 92,682 & 4.10 \\
\hline France & 5 & 3 & 24,645 & 54,799 & 3.30 \\
\hline Netherlands & 4 & 2 & 38,483 & 79,528 & 2.40 \\
\hline United States & 3 & 2 & 31,003 & 83,736 & 1.50 \\
\hline Israel & 4 & 1 & 31,743 & 84,613 & 1.50 \\
\hline United Kingdom & 2 & 1 & 26,738 & 48,995 & 2.60 \\
\hline World & 41 & 27 & 1411 & 3542 & 4.20 \\
\hline
\end{tabular}

Source: Modified from [32].

A significant $(p<001)$ reduction in the contribution of the agricultural workforce to the total workforce was noted in China (48\% to $18 \%$ ), India (61\% to $43 \%)$ and Brazil (24\% to 10\%) between 1991 and 2017 (Table 4). The advantage of large farms lies in the opportunity they provide to reduce labour costs by putting each worker to a task and encouraging specialization. This will help in improving both natural aptitudes and acquiring skill and speed, which is upscaled by constantly performing the same operation. A general explanation of the inverse relationship between farm size and productivity can be offered in terms of the low opportunity cost of family labour in a labour-surplus economy and the resultant variations in the input of human labour. Modernizing agriculture involved the introduction of new technology which required the increased use of capital in agriculture. Even with the use of some capital and new technology, however, many farm operations require the intensification of labour use, such as seedbed preparation, weeding, irrigating and harvesting. Thus, labour is also of critical importance in modern agricultural development.

In general, the per capita productivity of the agricultural workforce was significantly $(p<0.01)$ higher in countries with a low share $(<10 \%)$ of the population in the agrarian workforce. For instance, per person productivity (USD) was highest in Israel $(84,613$ USD) and the USA ( $83,736 \mathrm{USD})$, which had only $1 \%$ and $2 \%$, respectively, of their population as an agricultural workforce. The higher per capita productivity also implies large-scale mechanization with large size holdings. The results indicate that the per capita productivity of predominantly agrarian countries during 2017 ranged between 991 USD (Bangladesh) and 92,682 USD (Australia). A leap in growth in workers' productivity was recorded by China (7.1 times) and Brazil (4.6 times) between 1991 and 2017. This could be attributed to an increase in farm size (i.e., a larger area per worker) and the application of technologies $[33,34]$. The highest compound annual growth rate (CAGR) in per capita workers' productivity was registered by China $(7.9 \%)$, followed by South Africa $(6.9 \%)$ and Brazil $(6.1 \%)$. This could be attributed to a lower rate of capital accumulation and a more efficient use of all the factors of production [35] even in the absence of technology transfer, international investment, research and development, and aggregate scale effects. Trade affects economic growth through comparative advantage. The authors of [36] emphasize the supply-side role in sustainable growth, in which agriculture continues to play an important role but one different to what it was when demand-side effects were stronger [37]. Among the major agrarian-based countries studied in this paper, the growth rate was the lowest in Pakistan $(0.4 \%)$, which could possibly be due to the poor application of science and 
technology [38]. The literature generally discusses labour-surplus models, the empirical assessment of disguised unemployment such as in India and the backward sloping supply curve of labour.

\subsubsection{Equity in Ownership of Agriculture Landholding}

The average farm size across the world is determined by the countries with the largest number of farms and those with the largest share of the world's agricultural land. The landholding (unit area of agricultural land owned by a farm household) size increased significantly $(p<0.05)$ in most of developed countries from 1960 to 2000, while it decreased in developing countries (Table 5).

Table 5. Decadal trend in the average size of agricultural landholding during 1960-2018.

\begin{tabular}{|c|c|c|c|c|c|c|c|}
\hline \multirow{2}{*}{ Name of the Country } & \multicolumn{7}{|c|}{ Average Size of Agricultural Holding (ha) } \\
\hline & 1960 & 1970 & 1980 & 1990 & 2000 & Beyond 2000 & Trend \\
\hline Bangladesh & 1.4 & NA & 1.3 & NA & 0.3 & $0.8(2008)$ & Decrease \\
\hline India & 2.7 & 2.3 & 2.0 & 1.6 & 1.3 & $1.15(2011)$ & Decrease \\
\hline Pakistan & 3.5 & 5.3 & 4.7 & 3.8 & 3.1 & $2.24(2018)$ & Decrease \\
\hline Netherlands & 8.8 & 11.6 & 15.0 & 17.0 & 22.1 & NA & Increase \\
\hline Colombia & 22.6 & 26.3 & NA & 23.3 & 25.1 & NA & Increase \\
\hline France & 18.8 & 22.1 & 26.6 & 31.5 & 45.0 & NA & Increase \\
\hline United Kingdom & 40.7 & 55.1 & 65.4 & 70.8 & 70.9 & NA & Increase \\
\hline Brazil & 74.9 & 60.0 & 70.7 & 64.5 & 72.8 & NA & Stable \\
\hline USA & 122.6 & 157.6 & 168.1 & 187.0 & 178.4 & $177.2(2018)$ & Increase \\
\hline Uruguay & 195.3 & 214.1 & 234.4 & 286.1 & 287.4 & NA & Increase \\
\hline Australia & 1843.6 & 1993.0 & 2818.9 & 3601.7 & 3243.2 & NA & Increase \\
\hline
\end{tabular}

Note: NA-data not available. Source: compiled from [39-43].

The average landholding size across the major agriculturally important countries during 2000 was the highest in Australia (3243 ha), which, however, cannot be included as part of the generally improving trend in developed nations because the average farm size in Australia is an outlier relative to farms in other parts of the world [44]. While Uruguay (287 ha) and the USA (178 ha) also had considerably larger average landholding sizes, they were very low in India (1.3 ha) and Bangladesh (0.3 ha). The decrease over time in the average farm size in India could be attributed to the rise in population in the corresponding period. In larger countries, especially developed countries like the USA and Australia, farm size initially increased till 1990 and subsequently there has been a slight declining trend. In China, all agricultural land and homesteads in the suburban and rural areas are owned by rural collectives and are called collective land (jiti tudi) [45]. The current changes in land policy, which facilitate private ownership of agricultural land by individuals and enables easy land selling, have led to land consolidation [46].

Analysis of the compound annual growth rate (CAGR) during the period 1981 to 2011 in population and landholding size for the major countries of the world showed that Saudi Arabia had the highest population growth rate (3.08\%), followed by Israel $(2.43 \%)$ (Table 6$)$, while it was lowest in Cuba (0.46\%).

Except for Brazil and Sri Lanka, which recorded a CAGR of $0.07 \%$ and $0.01 \%$, respectively, the growth in per capita agricultural land during 1981-2011 was negative in other countries, implying that the per capita agricultural land availability shrank. A steep decline in per capita land availability was recorded in Pakistan, Bangladesh, and Israel, which could be attributed to higher population growth in these countries. The correlation coefficient value between the two variables was -0.74 , implying an inverse relationship between them. 
Table 6. Growth of population and landholdings in different countries over time.

\begin{tabular}{ccc}
\hline \multirow{2}{*}{ Country } & \multicolumn{2}{c}{ CAGR (\%) during 1981-2011 } \\
\cline { 2 - 3 } & Population & Per Capita Agricultural Land \\
\hline Australia & 1.30 & -1.29 \\
Bangladesh & 2.06 & -2.66 \\
Brazil & 1.56 & $\mathbf{0 . 0 7}$ \\
China & 1.03 & -1.19 \\
Cuba & 0.46 & $\mathbf{0 . 0 0}$ \\
France & 0.54 & -0.40 \\
India & 1.89 & -1.98 \\
Israel & 2.43 & -2.66 \\
Sri Lanka & 0.92 & $\mathbf{0 . 0 1}$ \\
Pakistan & 2.77 & -2.86 \\
Saudi Arabia & 3.08 & -1.69 \\
South Africa & 1.90 & -1.78 \\
United States & 1.08 & -1.69 \\
World & 1.47 & -0.90 \\
\hline
\end{tabular}

Note: Correlation coefficient was -0.74 between the two variables.

Holden and Otsuka [47] investigated the relationship between farm size distribution, productivity and equity in African countries with a hypothesis that the two former variables had an inverse relationship. They also emphasized that higher population pressure would intensify agriculture on smaller farms.

The equity in agricultural land ownership/operation is an important indicator of socioeconomic stability, at least in the agriculturally significant developing countries $[48,49]$. Besides this, land ownership inequality has been traditionally taken to explain high levels of income inequality especially in the countries where the agricultural sector predominates [50]. The Gini index of land ownership for the major agriculturally important countries for two points in time was taken into consideration in order to examine whether land ownership moves towards distributive justice (if the Gini index moved towards zero) or towards inequality (if the Gini index approached one) [51,52]. The significant $(p<0.05)$ reduction in the Gini index in Egypt 1961-2000 suggests that that country managed to ensure the increasing equality of land ownership distribution (Table 7). The trend was similar in India, though the reduction in the Gini value was not significant $(p>0.05)$. Bangladesh, Brazil, France, Pakistan and the USA recorded an increase in the index, suggesting movement of agricultural land ownership towards inequality, which also means agricultural land is being concentrated among fewer people. A study by Guerena and Wegerif [53] organized on behalf of the International Land Coalition indicates that around $84 \%$ of farms worldwide share $12 \%$ of the total agricultural land area, while just $16 \%$ of farms control the remaining $88 \%$ of agricultural land. They also state that the Gini coefficient of land ownership is 0.55 in Asia and 0.85 in Latin America.

Women accounted for $25.3 \%$ of global agricultural employment during 2019, while in the least developed countries this was 61\% and in India it was 55\% [54]. Data on female land ownership data available with FAO [55] indicates that in countries like the USA, Mexico, Brazil, Argentina and India the share of women agricultural landholders is in the range of 10-19\%, while in Canada, France and Spain it is in the range of 20-29\%. Many countries, like Algeria, Mali, Congo, Egypt and Saudi Arabia, have a range of 0-9\%, and in only a few countries, like Peru, Botswana and Italy, is it $30-39 \%$.

In Asia, women account for 35 to $60 \%$ of the agricultural labour force [56]. Women comprise, on an average, $43 \%$ of the agricultural workforce in developing countries, ranging from 20\% in Latin America to 50\% in East Asia and Sub-Saharan Africa. However, women have less access to agriculture-related assets, inputs and services than men [57]. It is estimated that with the provision of access to productive resources on the level of men, women could enhance the yield by $20-30 \%$, raising overall agricultural output in developing countries by two and a half to four percent. This gain in production could 
lessen the number of hungry people in the world by $12-17 \%$, besides increasing women's income [58].

Table 7. Gini index for agricultural land in agriculturally important countries.

\begin{tabular}{|c|c|c|c|c|}
\hline Country & Year & Gini Index Value & Inference & Source \\
\hline Aroonting & 1960 & 0.81 & & \multirow{4}{*}{ Frankema (2006) } \\
\hline Argentina & 1988 & 0.81 & Stable & \\
\hline \multirow{2}{*}{ Australia } & 1960 & 0.82 & \multirow{2}{*}{ Almost stable } & \\
\hline & 1971 & 0.81 & & \\
\hline \multirow{2}{*}{ Bangladesh } & 1977 & 0.42 & \multirow{2}{*}{ Increasing inequality } & \multirow{2}{*}{ Frankema (2006); FAO (2010) } \\
\hline & 1996 & 0.62 & & \\
\hline \multirow{2}{*}{ Brazil } & 1960 & 0.79 & \multirow{2}{*}{ Increasing inequality } & \multirow{2}{*}{ Frankema (2006); Hoffman (2011) } \\
\hline & 2006 & 0.85 & & \\
\hline \multirow[b]{2}{*}{ China } & 1988 & 0.50 & \multirow{2}{*}{ Almost stable } & \multirow{2}{*}{ Khan (2001) } \\
\hline & 2002 & 0.49 & & \\
\hline \multirow{2}{*}{ Egypt } & 1961 & 0.63 & \multirow{2}{*}{ Increasing equality } & \multirow{2}{*}{$\begin{array}{c}\text { Frankema (2006); Anríquez and } \\
\text { Bonomi (2008) }\end{array}$} \\
\hline & 2000 & 0.38 & & \\
\hline \multirow{2}{*}{ France } & 1988 & 0.53 & \multirow{2}{*}{ Increasing inequality } & \multirow{2}{*}{ FAO (1990); FAO (2010) } \\
\hline & 1999 & 0.58 & & \\
\hline \multirow{2}{*}{ India } & 1996 & 0.56 & \multirow{2}{*}{ Increasing equality } & \multirow{2}{*}{ Authors of the present study } \\
\hline & 2016 & 0.52 & & \\
\hline \multirow{2}{*}{ Netherlands } & 1989 & 0.55 & \multirow{2}{*}{ Almost stable } & \multirow{2}{*}{ FAO (1990); FAO (2010) } \\
\hline & 1999 & 0.57 & & \\
\hline \multirow{2}{*}{ Pakistan } & 1980 & 0.50 & \multirow{2}{*}{ Increasing inequality } & \multirow{2}{*}{$\begin{array}{l}\text { Anríquez and Bonomi (2008); } \\
\text { FAO (2010) }\end{array}$} \\
\hline & 2000 & 0.60 & & \\
\hline \multirow{2}{*}{ United States } & 1987 & 0.74 & \multirow{2}{*}{ Increasing inequality } & \multirow{2}{*}{$\begin{array}{c}\text { FAO (1990); Eastwood, Lipton, and } \\
\text { Newell (2004) }\end{array}$} \\
\hline & $1990 \mathrm{~s}$ & 0.78 & & \\
\hline
\end{tabular}

\subsection{Agriculture Landholdings in India}

The spatiotemporal changes in the extent of landholdings in India and various factors influencing them are discussed in the ensuing section.

\subsubsection{Spatiotemporal Changes in the Number of Landholdings}

The number of landholdings in India increased from 71.01 million (1970-1971) to 145.72 million (2015-2016) with an annual growth rate of $2.3 \%$. The highest increase in landholdings was observed among in the category of 'marginal farmers' ( $<1$ ha) with the percentage of their share of land increasing from 51 in 1970-1971 to 69 in 2015-2016. There was a corresponding decrease in the percentage of land held by large and medium farmers (Figure 5). The total area operated by small and marginal farmers has increased in India over time, at the expense of the area held by medium and large farmers. The agricultural area has shrunk from 162.3 million to 157.1 million hectares (Mha) during this period.

In the period 1970-1971, India had 2.76 million large farmers, who owned 50.06 Mha of agricultural land. The number of large farmers steadily decreased to 0.831 million and the ownership of agriculture land to 14.21 Mha by 2015-2016. The total area reduction of $2.76 \mathrm{Mha}$ formerly belonging to large farmers meant that the marginal/small farmers were enriched with 0.02 ha per head and at least five million such farmers were added. During this period, a total of 7.4 million new farmers were added despite a reduction in the total agricultural land of 2.5 Mha. The composition of landholding as per the 2015-2016 agriculture census shows a predominance of marginal holdings ( $<1 \mathrm{ha}$ ) constituting $69 \%$, followed by smallholdings (1-2 ha) with $18 \%$, semi-medium (2-4 ha) and medium (4-10 ha) together accounting for $13 \%$, and large holdings ( $>10$ ha) comprising only one percent. Compared to this, during the period 1970-1971, marginal holdings comprised only 51\%; 
however, smallholdings were $19 \%$, semi-medium and medium together were $26 \%$ and large holdings were $4 \%$ of the total (Figure 5$)$. This significant $(p<0.05)$ increase in the proportion of marginal farmers renders them an influential group in shaping the state of the agricultural economy of the country at present, while it is a matter of concern that shrinking landholdings impede the use of advanced technologies for enhancing agricultural productivity.

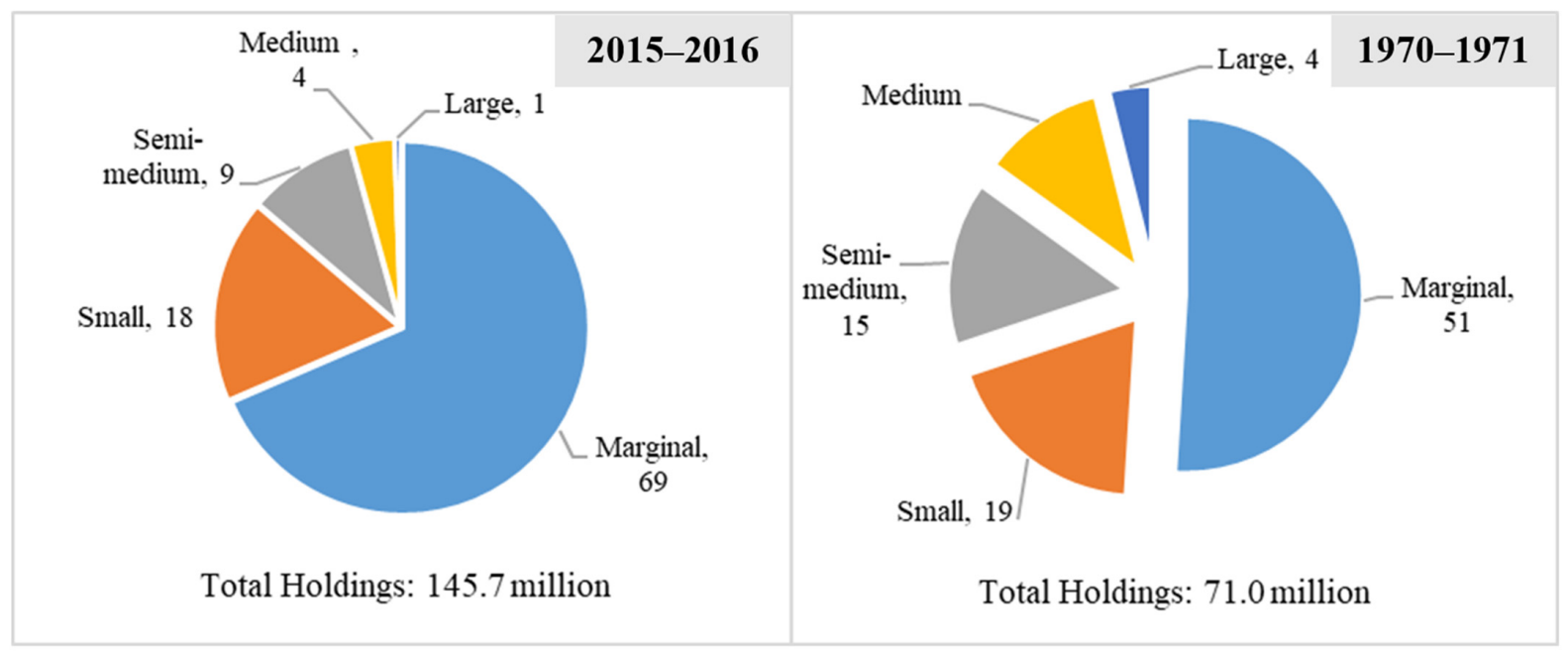

Figure 5. Farm size-wise composition of landholdings in India. Data source: adapted from [59].

The increasing number of small families who inherit agricultural land under the laws of inheritance has resulted in a steady decline in the average Indian landholding size per family from 2.28 ha (1970-1971) to 1.08 ha (2015-2016) (Figure 6). This implies that an average farm family in India works with less than half the land that their forefathers possessed 45 years ago, which factor affects their livelihood significantly. This has also led to an increasing number of farmers taking up other occupations, either by letting out the land for cultivation by tenants or by leaving the land fallow. The fallow land accounted for $5.9 \%$ of the total geographical area (19.33 Mha) $1970-1971$, which rose to $7.8 \%$ (25.8 Mha) by 2014-2015 [60]. In the USA, the extent of the fallow cropland area during 2012 was $40 \%$ [61]. Arable land in India (agricultural land), which is a sum of the net sown area and fallow (both current fallow and other fallow land) has increased by 5.94 Mha during the period from 1970-1971 to 2014-2015 (Figure 7).

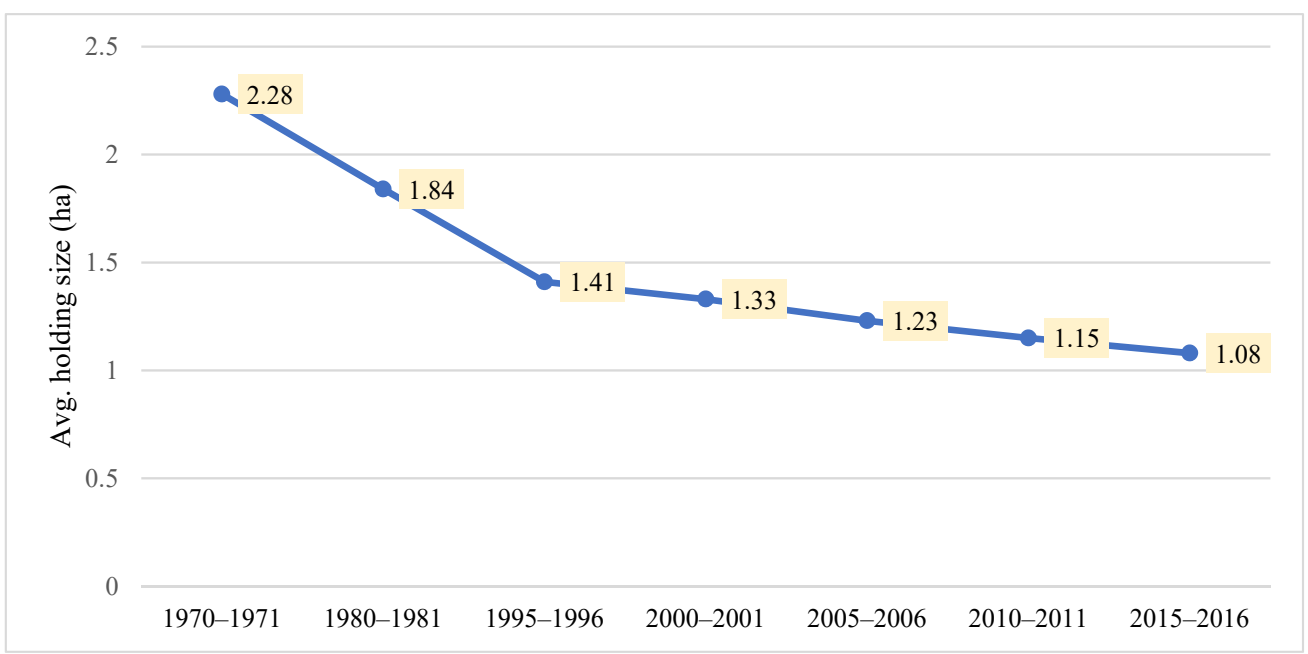

Figure 6. Trend of average landholding size in India (ha). Source: authors' calculations based on [59]. 


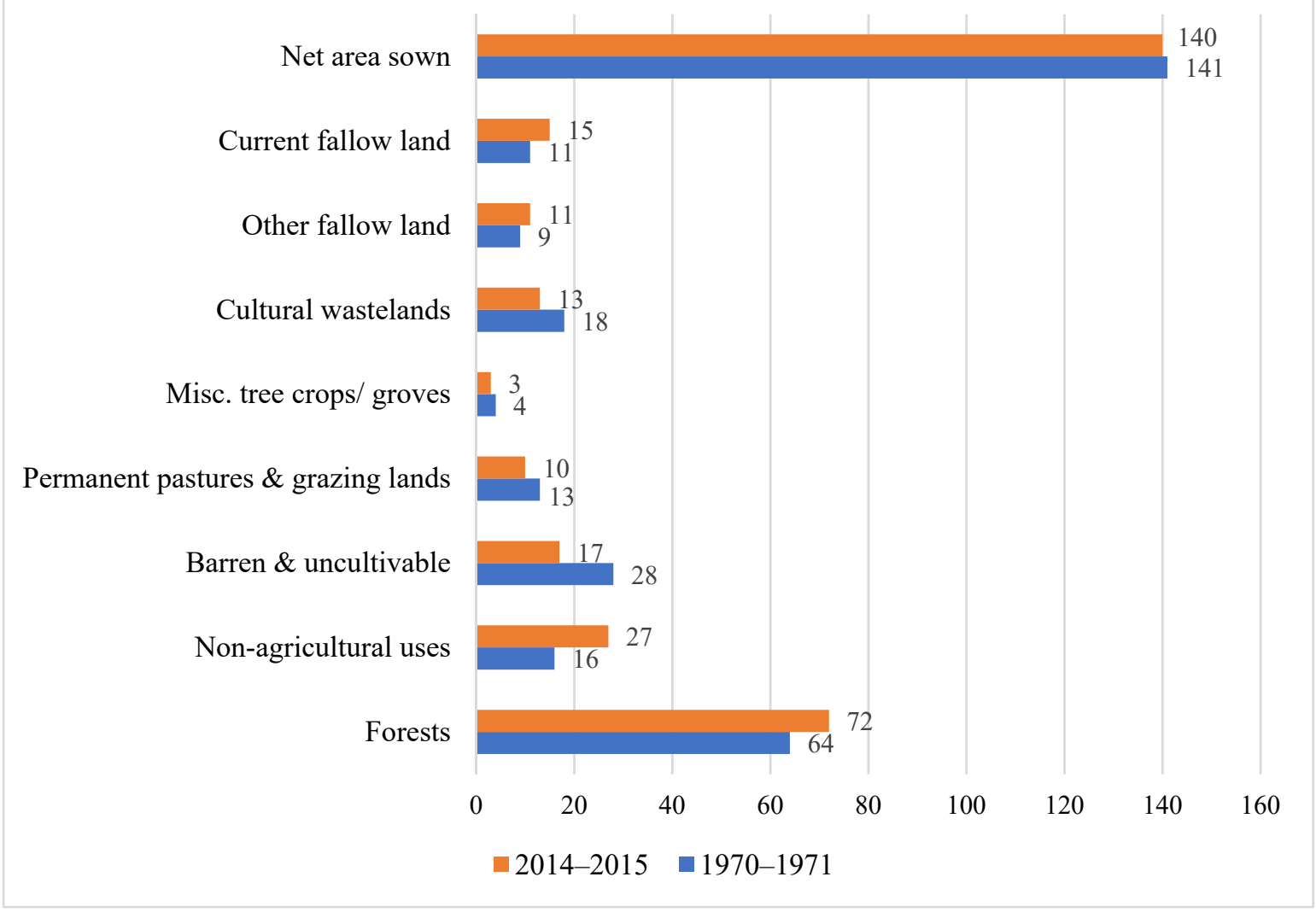

Figure 7. Land use categories in India (in Mha) (reporting the use of 92 and $94 \%$ of the total geographical area of $329 \mathrm{Mha}$ ). Source: [62].

The population in India had grown from 683 million 1980-1981 to 1210 million 2010-2011. The annual population growth rate decreased from $2.39 \%$ (1981 to 1991) to $1.77 \%$ (2001 to 2011). On the other hand, the growth rate of the number of agricultural holdings was $2.02 \%$ from 1981 to 1991, which decreased to $1.40 \%$ from 2001 to 2011 (Table 8). This means that although the absolute population and the corresponding number of landholdings had been increasing, the rate of increase declined or fluctuated, which indicates that when population growth tends to be stable and slower, the growth in the number of landholdings is likely to follow this pattern.

Table 8. Growth in Population vs Agricultural Holdings in India over Time.

\begin{tabular}{ccccc}
\hline Year & $\begin{array}{c}\text { Human Population } \\
\text { (Million) }\end{array}$ & $\begin{array}{c}\text { \% Annual } \\
\text { Change }\end{array}$ & $\begin{array}{c}\text { No. of Holdings } \\
\text { (Million) }\end{array}$ & $\begin{array}{c}\text { \% Annual } \\
\text { Change }\end{array}$ \\
\hline 1981 & 683 & & 89 & \\
1991 & 846 & 2.39 & 107 & 2.02 \\
2001 & 1029 & 2.16 & 121 & 1.31 \\
2011 & 1211 & 1.77 & 138 & 1.40 \\
\hline
\end{tabular}

Source: $[16,17]$.

The state-wise distribution of operational landholdings and agricultural area in India 2015-2016 (Supplementary Materials; Figures S1 and S2) reveals that Uttar Pradesh has the largest number of landholdings as per the 2015-2016 agricultural census with $16 \%$ of the country's total, while in terms of agricultural area, Rajasthan has the largest (13\%), followed by Maharashtra (13\%). Four states, viz., Uttar Pradesh, Maharashtra, Madhya Pradesh and Karnataka account for $40 \%$ of the total number of landholdings and have $42 \%$ of the agricultural area of India. The analysis of the landholding dynamics among the 
large states (in terms of agricultural area) between two census periods (Figure 8) showed that among the large states, the highest increase in the number of holdings was reported in Madhya Pradesh $(12.7 \%)$, while Tamil Nadu recorded a negative growth $(-2.2 \%)$. Except for Maharashtra, Bihar and Gujarat, the other large states recorded a decrease in agricultural land area between 2010-2011 and 2015-2016; the decrease in agricultural area was the steepest in Tamil Nadu (-8.0\%) followed closely by Kerala $(-7.7 \%)$, which could be attributed to significant industrialization in Tamil Nadu and faster urbanization and human settlements in rural and peri-urban areas in Kerala during the period [63].

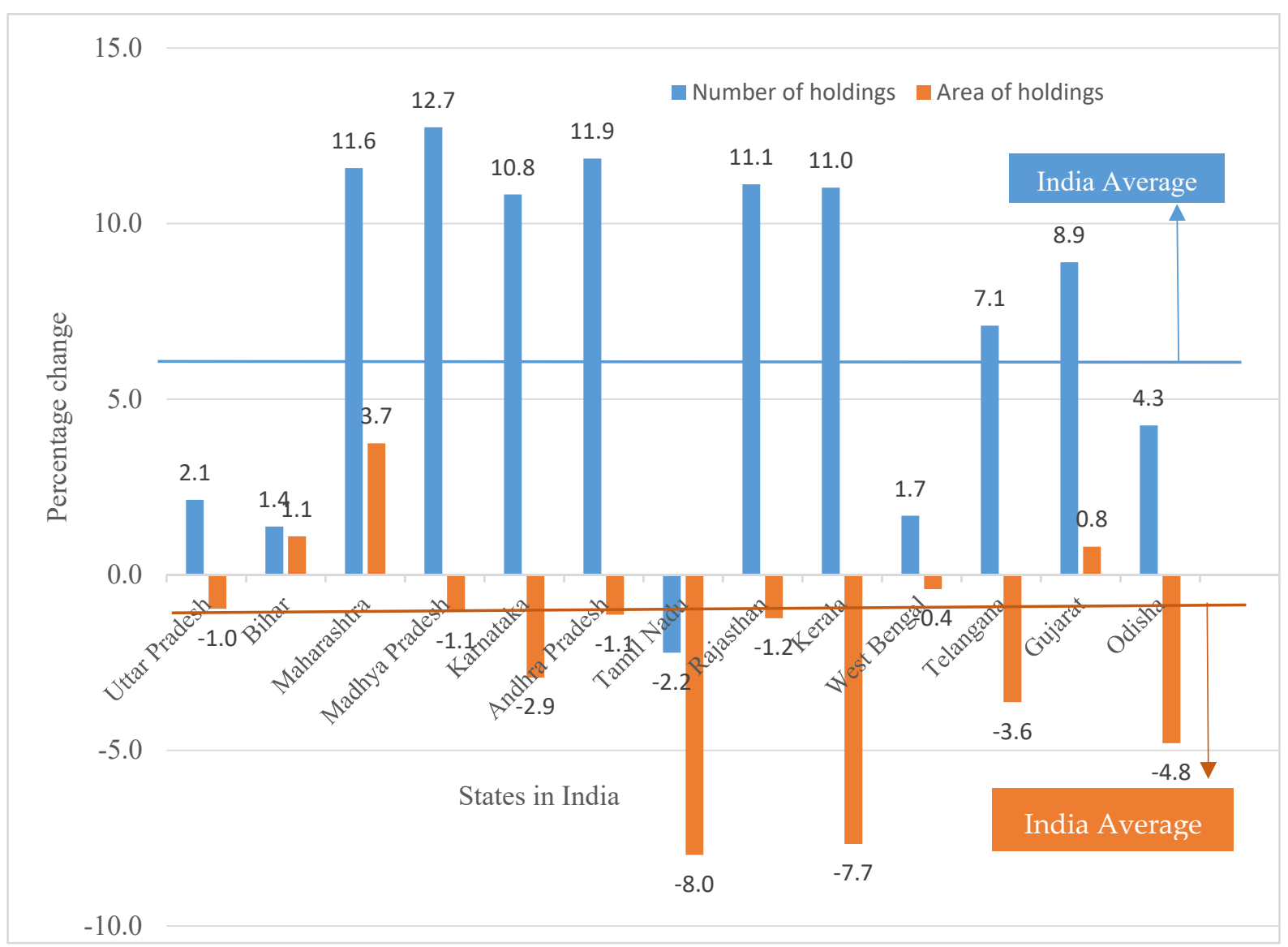

Figure 8. Percentage change in number and area of landholdings across different states in India between 2010-2011 and 2015-2016.

A critical analysis of the state-wise composition of agricultural landholdings by categories (Supplementary Materials; Figures S3 and S4) shows that the share of marginal farmers $(<1 \mathrm{ha}$ ) was the highest in the state of Kerala (97\%), closely followed by Bihar $(91 \%)$. Punjab had the least share of marginal farmers (14\%). Gujarat had the highest share of small farmers (30\%) compared to other states. On the other hand, medium farmers as a group were more prominent in the state of Punjab (62\%) than in any other state. The proportion of the large farmers was the highest in Rajasthan and Punjab (5\% each), which could be due to less productive, sandy, desert soils and land consolidation influenced by entrepreneurship, respectively.

The area held by different categories of farmers across the states indicated that medium holders, which held the largest proportion of land in India (44\%), accounted for $69 \%$ in Punjab, followed by Gujarat (60\%), Madhya Pradesh (54\%) and Rajasthan (52\%). The area held by marginal farmers was the highest in Kerala (61\%) while it was the lowest (2\%) in Punjab. The higher population density in Kerala $\left(859 \mathrm{~km}^{-2}\right)$ and its relative density 
$\left(550 \mathrm{~km}^{-2}\right)$ in Punjab could be the reason for this [64]. Large farmers held the largest share of land (29\%) in Rajasthan, while their share was the smallest in Bihar (1\%).

\subsubsection{Agriculture Workforce}

The total agricultural workforce, comprising cultivators and labourers, recorded a steady increase from 1991 (185.3 million) through 2001 (234.1 million) and 2011 (263.1 million) (Table 9), which was due to the increase in the proportion of agricultural labour. The proportion of farmers/cultivators (45\%) and agricultural labourers (55\%) during 2011 was the result of a change from farmer-dominated to labourer-dominated agriculture since 1991.

Table 9. Decadal change in the agricultural workforce in India (1991-2011).

\begin{tabular}{|c|c|c|c|c|c|c|}
\hline \multirow[b]{2}{*}{ Particulars } & \multicolumn{2}{|c|}{1991} & \multicolumn{2}{|c|}{2001} & \multicolumn{2}{|c|}{2011} \\
\hline & $\begin{array}{l}\text { Numbers } \\
\text { (Million) }\end{array}$ & $\%$ & $\begin{array}{l}\text { Numbers } \\
\text { (Million) }\end{array}$ & $\%$ & $\begin{array}{l}\text { Numbers } \\
\text { (Million) }\end{array}$ & $\%$ \\
\hline Cultivators (Main) & - & - & 103.6 & 44.3 & 95.9 & 36.5 \\
\hline Cultivators (Marginal) & - & - & 23.7 & 10.1 & 22.9 & 8.7 \\
\hline 1. Total & 110.7 & 59.7 & 127.3 & 54.4 & 118.8 & 45.1 \\
\hline Agricultural Labourers (Main) & - & - & 63.5 & 27.1 & 86.2 & 32.7 \\
\hline Agricultural Labourers (Marginal) & - & - & 43.3 & 18.5 & 58.2 & 22.1 \\
\hline 2. Total & 74.6 & 40.3 & 106.8 & 45.6 & 144.3 & 54.9 \\
\hline Total Agricultural Workers $(1+2)$ & 185.3 & 100 & 234.1 & 100 & 263.1 & 100 \\
\hline Annual Growth Rate (\%) & \multicolumn{2}{|c|}{2.3} & \multicolumn{2}{|c|}{2.4} & \multicolumn{2}{|c|}{1.2} \\
\hline
\end{tabular}

Source: authors' estimates based on data from $[65,66]$.

The age break-down of the agricultural workforce in 1971 indicates that while almost $60 \%$ of the force comprised youth (15-34 years), middle-aged persons accounted for $31 \%$. These figures were 45 and $42 \%$, respectively, for the year 2011. The overall trend showed that the agricultural workforce is aging gradually over time (Figure 9). There was a significant $(p<0.05)$ increase in the proportion of middle-aged farmers between 1971 and 2011. A similar trend has been observed in some other developing countries, viz., Botswana in Africa, Panama in Central America, and Myanmar and Philippines in Asia [67]. It has been reported that given an alternative, $45 \%$ of Indian farmers wish to quit agriculture [68]. Recognizing this, the government of India instituted a scheme "Attracting and Retaining Youth in Agriculture (ARYA)" in 2015-2016.

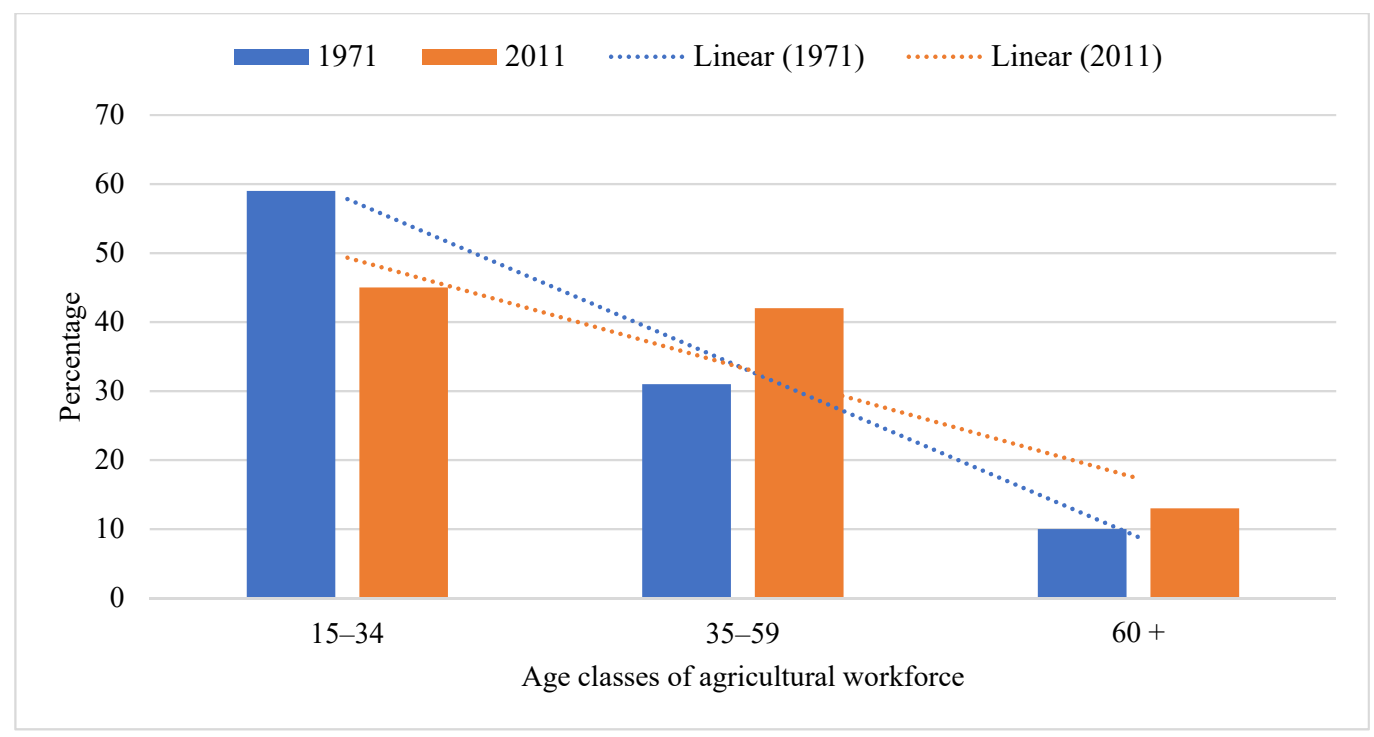

Figure 9. Percentage distribution of the agricultural workforce by age. 


\subsubsection{Individual, Family, and Institutional Ownership of Landholdings}

Individuals account for a majority $(85.5 \%$ in number and $81.6 \%$ in extent) of the landholders in India. Joint ownership of agricultural land accounts for $17 \%$ of the area, which is managed by $14.3 \%$ of the farmers. Institutions, like temples and other religious institutions across India, own one percent of the total agricultural land (Figure 10). This means that individual farmers and joint-owning farm families have exclusive rights to almost all agricultural land in India.

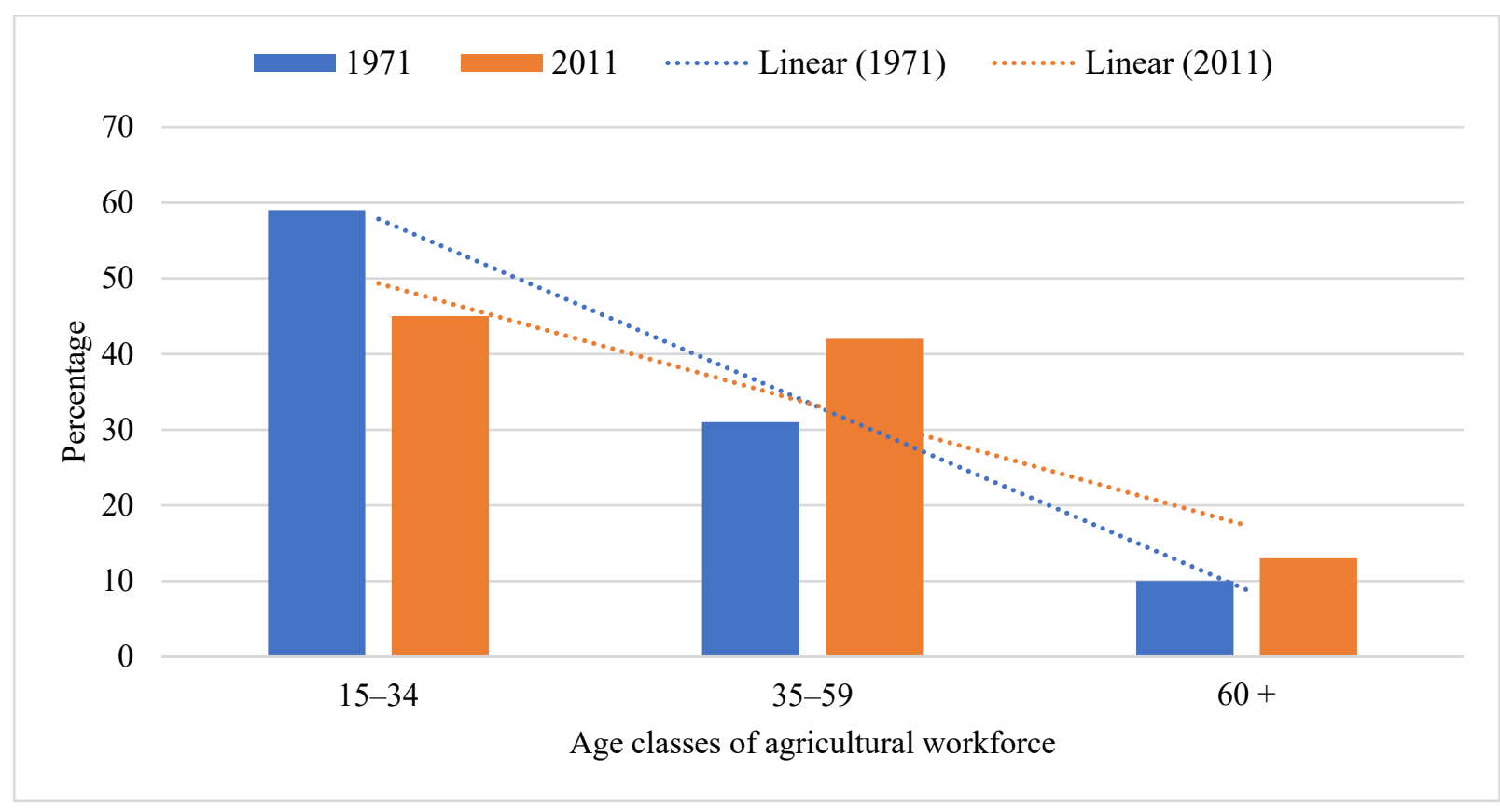

Figure 10. Percentage of individual, joint and institutional ownership of land in 2015-2016. (Total number:146 million; total area:157 million ha).

During the 1960s and 70s, every state passed legislation on tenancy reforms to ensure equity in asset distribution in rural areas; prevent agricultural lands from being diverted to industrial uses; discourage absentee landlordism in agriculture; and minimize disparity in rural wealth distribution. These legislative restrictions resulted in decreased land access for the landless and also for more efficient producers [69]. The tenancy reform legislation affected landless agricultural labourers as the landowners preferred to keep the land fallow rather than renting it out because of the risk of losing ownership of the land [70].

\subsubsection{Equity in Land Ownership}

Equity in ownership of land could be viewed from three dimensions, viz., gender, farm size (marginal to large farmers), and social class. To understand equity in the possession of agricultural land by different land-size classes, Gini indices were established for two points in time for the whole of India and its major states. At present, the land ceiling ranges from 9 to 54 standard acres and surplus land must be redistributed in favour of landless agricultural labourers. Some states such as West Bengal successfully implemented ceiling laws, with $40 \%$ of the surplus land redistributed to landless agricultural households [71,72].

\section{Equity across States}

The equity in landholding was assessed among the agriculturally important states of India, which account for $70 \%$ of the country's total agricultural areas, based on the proportion of land owned by different farm size categories. The Gini index decreased by 7\% between 1995-1996 (0.56) and 2015-2016 (0.52) at the national level, which indicates that the ownership of land is slowly tending towards equitable distribution (Table 10) and 
that inequality is decreasing, although absolute equity may be a distant reality. Among the states, the maximum reduction in Gini value was recorded in Bihar (29\%) followed by Odisha $(25 \%)$, while the lowest reduction was recorded in Karnataka ( $2 \%)$. This analysis does not mean that poor or marginal/small farmers are getting richer. In the context of increased competition, agricultural holdings must become larger in terms of the area under operation, so that majority of the modern technologies could be adopted on such farms to make them viable and sustainable [73,74].

Table 10. Gini index of land ownership among different states in India.

\begin{tabular}{cccc}
\hline State & 1995-1996 & 2015-2016 & $\begin{array}{c}\text { Percent Reduction in } \\
\text { Inequality }\end{array}$ \\
\hline AP & 0.50 & 0.46 & 8 \\
Assam & 0.53 & 0.50 & 6 \\
Bihar & 0.48 & 0.34 & 29 \\
Gujarat & 0.46 & 0.44 & 4 \\
Karnataka & 0.50 & 0.49 & 2 \\
Maharashtra & 0.47 & 0.45 & 4 \\
Odisha & 0.44 & 0.33 & 25 \\
Punjab & 0.46 & 0.42 & 8 \\
Tamil Nadu & 0.50 & 0.46 & 11 \\
UP & 0.46 & 0.41 & 16 \\
West Bengal & 0.37 & 0.31 & $\mathbf{7}$ \\
All-India & $\mathbf{0 . 5 6}$ & $\mathbf{0 . 5 2}$ & \\
\hline
\end{tabular}

Source: authors' estimates from data sourced from [16].

\section{Equity across Social Classes}

In India, socially underprivileged people who have been met with historical injustice have been classified through an act of parliament as scheduled castes (SC) and scheduled tribes (ST). The 2011 census shows that the SC and ST populations in the country account for 16.2 and $8.2 \%$ of the population, respectively. The share of the number and extent of agricultural landholdings 2010-2011 and 2015-2016 were 12 and 9\% (for SC) and 9 and 11\% (for ST), respectively (Table 11).

Table 11. Landholding among scheduled castes (SC) and scheduled tribes (ST) in India.

\begin{tabular}{|c|c|c|c|c|c|c|c|c|c|c|}
\hline \multirow[b]{2}{*}{ Particulars } & \multicolumn{4}{|c|}{ 2015-2016 } & \multicolumn{4}{|c|}{ 2010-2011 } & \multicolumn{2}{|c|}{ Annual Change (\%) } \\
\hline & No. & $\%$ & $\begin{array}{c}\text { Area } \\
\text { (Mha) }\end{array}$ & $\%$ & No. & $\%$ & $\begin{array}{c}\text { Area } \\
\text { (Mha) }\end{array}$ & $\%$ & No. & Area \\
\hline SC holdings & 17,355 & 12 & 13.526 & 9 & 17,099 & 12 & 13.721 & 9 & 0.30 & -0.28 \\
\hline ST holdings & 12,701 & 9 & 17.908 & 11 & 12,005 & 9 & 18.221 & 11 & 1.16 & -0.34 \\
\hline SC/ST total & 30,056 & 21 & 31.434 & 20 & 29,104 & 21 & 31.942 & 20 & 0.65 & -0.32 \\
\hline
\end{tabular}

With a population of $24.4 \%$, the SC and ST holdings accounted for $21 \%$ of the number and $20 \%$ of the extent of total agricultural landholdings. The average holding size of SC and ST farmers was 0.78 and 1.41 ha, respectively, 2015-2016. This indicates that the share of land of ST farmers was higher than that of SC farmers, though the average landholding size decreased for both during the period 2011-2016. There was a significant increase $(p<0.05)$ in the number of agricultural landholdings owned by SC $(0.30 \%$ per annum $)$ and ST farmers (1.16\% per annum) from 2011 to 2016, while the extent of land owned by these groups decreased, although insignificantly $(p>0.05 ;<1 \%$ per annum). India must strengthen its policies and support schemes to enhance the ownership of these socially marginalized groups and to strengthen their operational rights [75,76]. 


\section{Gender Role-Women Farmers' Share}

The share of women cultivators in India increased to $30 \%$ in 2011 , from $11 \%$ in 1970 , as per the agriculture census of India [16]. Similarly, their share of agriculture labour was 33 and 54\% during 1971 and 2011, respectively (Figure 11). The share of female-owned landholdings at the all-India level has increased significantly $(p<0.05)$ in number and area of landholdings, which is a sign of improving gender equality in this period. The growth rate in the number of female holdings was higher $(8.2 \%)$ than that of the area operated by them (5\%) (Figure 12).

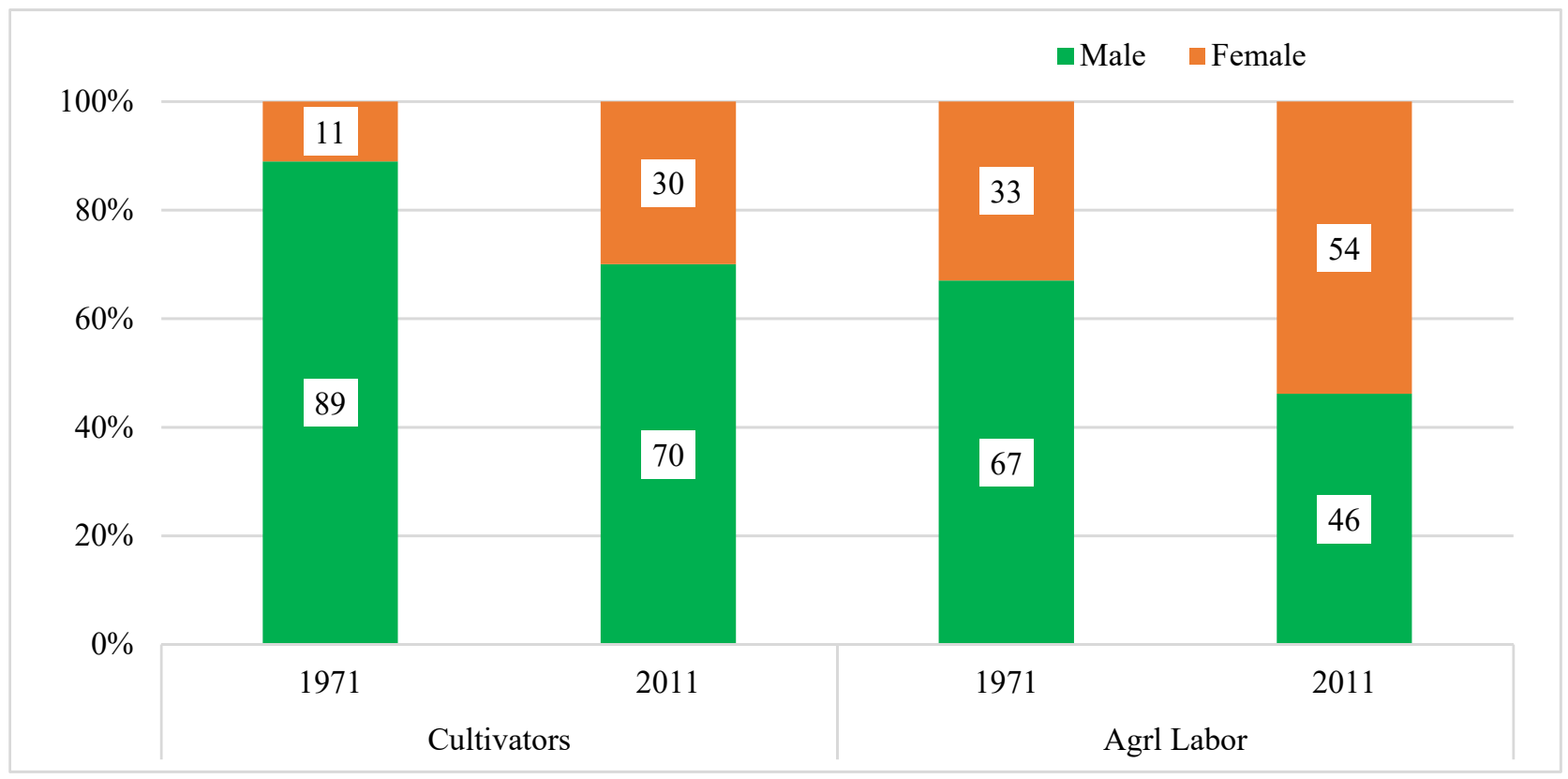

Figure 11. Gender breakdown of the agricultural workforce in India.

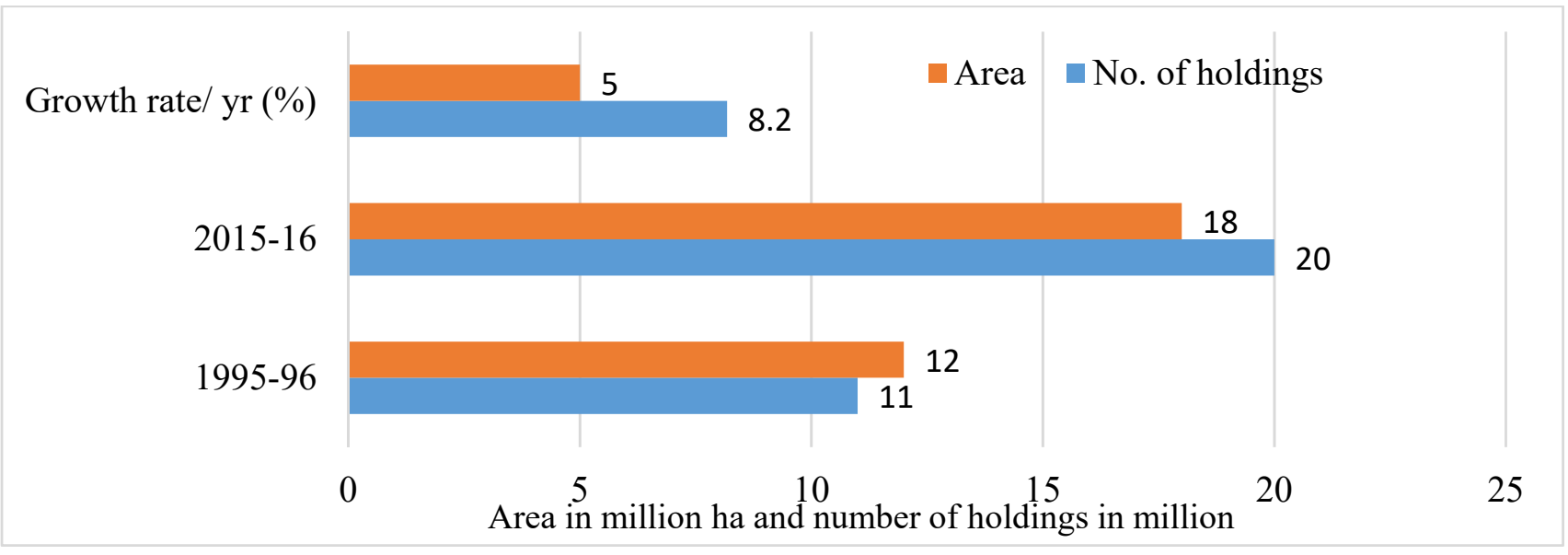

Figure 12. Dynamics of female landholdings in India.

Within India, Meghalaya, a small hilly state in the northeast, has the highest share of female landholding (34\% of the number of landholdings and $28 \%$ of the operational area), followed by Andhra Pradesh (30\% holdings and 27\% area). Kerala, Telangana, Karnataka and Tamil Nadu were the other states in India that were better than the national average in terms of female land ownership (14\% holdings and 12\% area) (Supplementary Materials; Figure S5). The overall trends in female land ownership could be linked to the social and cultural practices and legal provisions in their respective countries. In India, inheritance is 
the primary means of acquiring ownership of agricultural land. Patriarchal practices in India largely lead to the denial of equal ownership of property, including land, between men and women. The Hindu Succession (Amendment) Act (HSAA) 2005 provides clear rights to women on par with men. A woman can also inherit the self-acquired agricultural land of her deceased husband, and a widow who is remarrying can inherit the land of her deceased husband. Female land ownership contributes to alleviating her family's risk of poverty and vulnerability to violence and the expansion of her family's livelihood options [77]. Having land in women's names could increase agricultural productivity, given the increase in male out-migration and the growing number of female-headed households, and this could have far-reaching implications not only for women's status but also for improving production in agriculture.

Over the years, as the number of families has increased, the number of landholdings has also increased with fragmentation into economically unviable parcels and plots. Farmers find their pieces of land too small to be a viable source of livelihood, and the banks hesitate to accept such land as collateral and thus deny access to credit. Guerena and Wegerif [53] have also argued that the cost of land inequality is reflected in more poverty and social conflict, environmental degradation, food insecurity and gender imbalances. Ownership of land by women gives them access to credit, education and technical assistance, among other things [78]. These studies emphasize the need for better equity for women in the Indian context.

\subsubsection{Tenancy and Land Reforms}

Land access involves providing possession and land tenure refers to securing and broadening of the rights to those who possess the land. Typically, a landless labourer lacks access to land and also tenure rights. In some cases, they may not have possession but could have secured rights [69].

Tenant farming has historically been reported in several countries in different forms. During the 1970s, some countries had a higher rate of tenant farming — for instance, Vietnam had $70 \%$ of its farms under tenancy, with an equal proportion of agricultural land under their control [79], followed by Iran (67\% of farms and control over 73\% of land) and Egypt ( $62 \%$ of farms and $57 \%$ of land). In the corresponding period, in India, the proportion of tenant farming was $27 \%$ of total farms. In developed countries like France and Belgium, the extent of tenant farming was 66 and $68 \%$, respectively, while it was about $35 \%$ in the United Kingdom in 2002 [80].

The extent of area operated under tenancy across different states of India was analysed. It may be noted that at the all-India level, the extent of the agricultural area under tenant farming has declined during the last six decades (i.e., 1953-1954 to 2010-2011) from 20.6\% to $10.4 \%$ (Table 12). Though leasing is prohibited, it still occurs in different states with small deviations. The phenomenon of tenancy appears to be rampant in states experiencing good agricultural growth [81]. Among these states, tenancy was more popular in Andhra Pradesh (35.7\%), Punjab (24.4\%) and Bihar (22.7\%) 2010-2011. The share has increased in Andhra Pradesh and Bihar, while in Punjab it has decreased in the last 57 years. Tenant farming results in declining land productivity and increasing land degradation [82]. The insecure future rights of tenants make them reluctant to invest adequately in measures necessary to conserve land resources [83]. 
Table 12. Leased-in area (\%) in various states during 1953-1954 and 2010-2011.

\begin{tabular}{cccc}
\hline States & $\mathbf{1 9 5 3 - 1 9 5 4}$ & $\mathbf{2 0 1 0 - 2 0 1 1}$ & Annual Growth Rate (\%) \\
\hline Andhra Pradesh & 21.2 & 35.7 & 1.20 \\
Assam & 43 & 4.2 & -1.58 \\
Bihar & 12.4 & 22.7 & 1.40 \\
Gujarat & 19.4 & 5.8 & -1.23 \\
Haryana & 39.8 & 14.8 & -1.10 \\
Jammu and Kashmir & 22.1 & 0.2 & -1.74 \\
Karnataka & 21.5 & 6.9 & -1.19 \\
Kerala & 20.2 & 8.9 & -0.98 \\
Madhya Pradesh & 19.8 & 5.1 & -1.21 \\
Maharashtra & 19.7 & 3.4 & -1.45 \\
Odisha & 12.6 & 17 & 0.61 \\
Punjab & 39.8 & 24.4 & -0.68 \\
Rajasthan & 21 & 7.1 & -1.16 \\
Tamil Nadu & 27 & 13.5 & -0.88 \\
Uttar Pradesh & 11.4 & 7.9 & -0.57 \\
West Bengal & 25.4 & 14.7 & -0.74 \\
All-India & $\mathbf{2 0 . 6}$ & $\mathbf{1 0 . 4}$ & $-\mathbf{0 . 8 7}$ \\
\hline
\end{tabular}

Source: Adapted from References [84,85].

Indian farmers practise four types of land leasing-fixed money, fixed produce, through a share in the farm produce and through usufructuary mortgages. Furthermore, five sets of tenancy laws prevail in the major states of India that govern agricultural land leasing. Many states have combined legislations to improve the situation of tenants with either a complete prohibition on leasing land or with provisions to provide tenants who had been on the land for some time with very strong property rights, which is likely to have limited the supply of new land to the rental market [68]. These state-specific tenancy laws have specific restrictions (Supplementary Materials; Table S1). Land reforms have been reported to have aided in mitigating the agrarian crisis in South India [86].

\section{Conclusions and Recommendations}

This study is expected to enable social planners and decision makers to consider multiple attributes of agricultural growth and development that need to be assessed simultaneously when implementing programs for modernizing existing schemes for growth. This paper tries to capture the general growth indicators, which are conflicted as well as complementary in nature. This study primarily analysed two approaches to enhancing the role of agriculture in the context of developing countries such as India: (a) the role of farm size as a determinant of efficiency and equity, and (b) the benefits of increasing farm size for implementing modern technologies that are generally optimal at larger farm size and also have positive impact on gender-based adoption. While farm economic efficiency is the key variable in the assessment of the role of agriculture in macro-economic growth, other indicators such as socio-ecological equity and gender may also have high significance.

The results have several implications for developing countries such as India, which is engaged in consolidating holdings and increasing farm size for the effective implementation of mechanization and to increase farm productivity. Firstly, from an economic perspective the proposed model could enhance farm efficiency, but planners need also to address the likely impact on the agricultural workforce, who often have disguised employment status. Secondly, the impact of large-scale mechanization on soil ecology and the restoration of gender equality needs to be addressed. The family ownership of farms and declining size of holdings in Asian countries as opposed to increased farm size under corporate farming in developed countries like the USA is an important point that needs to be considered when adopting large-scale mechanization. Thus, the social and ecological parameters of the Asian continent require addressing when dealing with governance issues, including tenurial rights. 
Thirdly, from the point of view of efficiency, the economic viability of increasing farm size depends on several socio-economic factors, natural resource endowments and other environmental characteristics of the region which, of course, were not part of this study. Our analysis shows that the expansion of crop area is extremely difficult in the context of high population density states, and could be achieved only at high capital costs, which could negatively impact the availability of capital for existing cropland.

Fourthly, from an equity point of view, the declining share of agricultural land belonging to marginalized communities is a matter of concern. Further, most of these farmers lack the capital to invest in irrigation infrastructure. Therefore, it makes sense to empower these farmers with proper irrigation and market infrastructure through farmers' producer organizations.

Supplementary Materials: The following are available online at https:/ /www.mdpi.com/article/10 .3390/su131810225/s1, Figure S1: State-wise number of landholdings in India by State during 20152016, Figure S2: State-wise area of landholdings in India during 2015-2016, Figure S3: Percentage of number of landholdings across size categories in different Indian States during 2015-2016, Figure S4: Percentage of extent of landholdings across size categories in different Indian States during 2015-2016, Figure S5: Share of female landholdings in selected states in India during 2015-2016, Table S1: Tenancy laws in various Indian states and restrictions imposed.

Author Contributions: Conceptualization, K.K. and P.K.; Methodology, K.K., S.R. and B.G.K.; software, K.K.; validation, K.K., S.R., R.B. and P.K.; formal analysis, K.K. and S.S.; investigation, K.K. and S.S.; resources, K.K.; data curation, K.K., B.G.K. and S.S.; writing-K.K., S.S. and P.K.; writingreview and editing, K.K., P.K., S.R., B.G.K. and R.B.; visualization, S.S.; supervision, K.K.; project administration, K.K.; funding acquisition, K.K., P.K., S.R. and B.G.K. All authors have read and agreed to the published version of the manuscript.

Funding: This research received no external funding.

Institutional Review Board Statement: Not applicable.

Informed Consent Statement: Not applicable.

Data Availability Statement: All data as required have been included in the paper. Not applicable.

Conflicts of Interest: The authors declare no conflict of interest.

\section{References}

1. Kanianska, R. Agriculture and its impact on land-use, environment, and ecosystem services. In Landscape Ecology—The influences of Land-Use and Anthropogenic Impacts of Landscape Creation; Almusad, A., Ed.; Intech Open: Rijeka, Croatia, 2016. [CrossRef]

2. FAO. 2021. Available online: http://www.fao.org/world-agriculture-watch/tools-and-methodologies/definitions-andoperational-perspectives/family-farms/en/ (accessed on 15 June 2021).

3. Grigg, D. An Introduction to Agricultural Geography, 2nd ed.; Routledge: London, UK, 1989; p. 237.

4. Sklenicka, P.; Zouhar, J.; Trpakova, I.; Vlasa, J. Trends in land ownership fragmentation during the last 230 years in Czechia, and a projection of future developments. Land Use Policy 2017, 67, 640-651. [CrossRef]

5. International land Coalition and Oxfam. 2020. Available online: https://www.landcoalition.org/en/newsroom/new-reportreveals-land-inequality-worse-we-thought-and-fueling-other-inequalities/ (accessed on 15 June 2021).

6. Rapsomanikis, G. The Economic Lives of Smallholder Farmers an Analysis Based on Household Data from Nine Countries; Food and Agriculture Organization of the United Nations: Rome, Italy, 2015; 48p.

7. Erickson, L.; Vollrath, D. Dimensions of Land Inequality and Economic Development; International Monetary Fund: Washington, DC, USA, 2004; 24p.

8. Krishnamurthy, L; Khandelwal, S. Agriculture journal: China vs. India by the numbers. The Wall Street Journal, 20 September 2011.

9. Kijima, Y.; Tabetando, R. Efficiency and equity of rural land markets and the impact on income: Evidence in Kenya and Uganda from 2003 to 2015. Land Use Policy 2020, 91, 104416. [CrossRef]

10. Lawry, S.; Samii, C.; Hall, R.; Leopold, A.; Hornby, D.; Mtero, F. The impact of land property rights interventions on investment and agricultural productivity in developing countries: A systematic review. Campbell Syst. Rev. 2014, 10, 1-104. [CrossRef]

11. Akinyemi, B.E.; Mushunje, A. Land ownership and usage for agriculture: Empirical evidence from South African living conditions survey. Cogent Soc. Sci. 2019, 5, 1663691. [CrossRef]

12. Banski, J. Three Decades of Transformation in the East-Central European Countryside; Springer: Berlin/Heidelberg, Germany, 2017. 
13. Husain, I. Agriculture Land and Ceiling Laws in India: An Overview; The Law Bridge Publishers: Ahmedabad, India, 2019. Available online: https://thelawbrigade.com/land-laws/agriculture-land-and-ceiling-laws-in-india-an-overview/ (accessed on 6 June 2021).

14. Mishra, K.; Sam, A.G. Does Women's land ownership promote their empowerment? Empirical evidence from Nepal. World Dev. 2016, 78, 360-371. [CrossRef]

15. World Bank. 2020. Available online: https:/ / data.worldbank.org/indicator/AG.LND.AGRI.K2 (accessed on 10 January 2020).

16. Agricultural Census. Available online: https://agcensus.nic.in/ (accessed on 10 January 2020).

17. Census of India. Available online: https:/ / censusindia.gov.in/ (accessed on 11 January 2020).

18. Gini, C. Variabilita e mutabilita. In Memorie di metodologica Statistica; Pizetti, E., Salvemini, T., Eds.; Libreria Eredi Virgilio Veschi: Rome, Italy, 1955.

19. Bauluz, L.; Govind, Y.; Novokmet, F. Global Land Inequality; HAL-SHS: Lyon, France, 2010; 24p.

20. Flynn, M.E. Tools for Analyzing Cross-National Military Deployment and Basing Data. Available online: https://github.com/ meflynn/troopdata (accessed on 5 June 2021).

21. Cassman, K.; Wood, S. Cultivated systems. In Ecosystems and Human Well-Being, Millennium Ecosystem Assessment (Current State and Trends); Island Press: Washington, DC, USA, 2005; Volume 1, Chapter 26.

22. Queiroz, M.; Marcos, S.J.; Yao, S.; Carter, C.A. Agriculture in Brazil and China: Challenges and Opportunities; INTAL-ITD: Buenos Aires, Argentina, 2006. Available online: https:/ / publications.iadb.org/publications/english/document/Agriculture-in-Braziland-China-Challenges-and-Opportunities.pdf (accessed on 10 March 2021).

23. FAO. Available online: http://www.fao.org/3/y4252e/y4252e06b.htm\#N10 (accessed on 15 April 2021).

24. World bank. Available online: https:/ / data.worldbank.org/indicator/ag.lnd.agri.zs (accessed on 21 May 2021).

25. Huang, J.; Rozelle, S. China's 40 years of agricultural development and reform. In China's 40 Years of Reform and Development: 1978-2018; Zheng, X., Ed.; Springer: Berlin, Germany, 2019; pp. 487-506. [CrossRef]

26. USDA. 2021. Available online: https:/ / www.usda.gov/media/blog/2020/03/05/look-agricultural-productivity-growth-unitedstates-1948-2017 (accessed on 21 April 2021).

27. FAO. Identifying the "Family Farm" An Informal Discussion of the Concepts and Definition; FAO: Rome, Italy, 2014; 30p.

28. FAO. 2014. Available online: http://www.fao.org/family-farming/detail/en/c/281544/ (accessed on 15 April 2021).

29. FAO. Available online: http://www.fao.org/india/fao-in-india/india-at-a-glance/en/ (accessed on 16 April 2021).

30. Chand, R. New Farm Acts—Understanding the Implications; NITI Working Paper Series 1/2020; NITI Aayog, Government of India: New Delhi, India, 2020; 20p.

31. Gollin, D. Agricultural productivity and economic growth. In Handbook of Agricultural Economics; Elsevier: Amsterdam, The Netherlands, 2010; Chapter 73; pp. 3825-3866. [CrossRef]

32. Roser, M. Employment in Agriculture; Our World In Data: Oxford, UK, 2019. Available online: https://ourworldindata.org/ employment-in-agriculture (accessed on 20 June 2021).

33. Gollin, D.; Lagakos, D.; Waugh, M.E. Agricultural productivity differences across Countries. Am. Econ. Rev. 2014, 104, 165-170. [CrossRef]

34. UNCTAD. The Least Developed Countries Report 2015; UNCTAD: Geneva, Switzerland, 2015; Chapter 2.

35. Arnal, E.; Förster, M. Growth, employment and inequality in Brazil, China, India and South Africa: An overview. In Tackling Inequalities in Brazil, China, India and South Africa; OECD Publishing: Pairs, France, 2010; pp. 13-55. [CrossRef]

36. Yenokyan, K.; Seater, J.J.; Arabshahi, M. Economic growth with trade in factors of production. Int. Econ. Rev. 2014, 55, 223-254. [CrossRef]

37. Zhang, Y.; Diao, X. The changing role of agriculture with economic structural change-The case of China. China Econ. Rev. 2020, 62, 101504. [CrossRef]

38. Mahmood, Z.; Siddiqui, R. State of technology and productivity in Pakistan's manufacturing industries: Some strategic directions to build technological competence. Pak. Dev. Rev. 2000, 39, 1-21. [CrossRef]

39. FAO. World Food and Agriculture-FAO Statistical Yearbook-2013. 2013. Available online: http://www.fao.org/3/i3107e/i310 7e01.pdf (accessed on 15 June 2021).

40. Bangladesh Bureau of Statistics. 2017. Available online: http:/ /www.bbs.gov.bd/ (accessed on 1 May 2021).

41. Dawn. 2018. Available online: https://www.dawn.com/news/1439041 (accessed on 1 June 2021).

42. Statista. Available online: https:/ / www.statista.com/statistics/196106/average-size-of-farms-in-the-us-since-2000/ (accessed on 23 April 2021).

43. Wang, X.; Yamauchi, F.; Otsuka, K.; Huang, J. Wage Growth, Landholding, and Mechanization in Chinese Agriculture. World Dev. 2016, 86, 30-45. [CrossRef]

44. Lowder, S.K.; Skoet, J.; Raney, T. The number, size, and distribution of farms, smallholder farms, and family farms worldwide. World Dev. 2016, 87, 16-29. [CrossRef]

45. Habitat International Coalition. Available online: http://www.hic-gs.org/articles.php?pid=1553 (accessed on 15 May 2021).

46. Nie, F.; Fang, C. Family farming in China: Structural changes, government policies and market development for growth inclusive of smallholders. Presented at the FAO, Rome, Italy, 13 December 2013.

47. Holden, S.T.; Otsuka, K. The roles of land tenure reforms and land markets in the context of population growth and land use intensification in Africa. Food Policy 2014, 48, 88-97. [CrossRef] 
48. Bautista, R.M.; Thomas, M. Agricultural growth linkages in Zimbabwe: Income and equity effects. Agrekon 1999, $38,66-77$. [CrossRef]

49. Azadi, H.; Vanhaute, E. Mutual effects of land distribution and economic development: Evidence from Asia, Africa, and Latin America. Land 2019, 8, 96. [CrossRef]

50. Carter, P.L.; Reardon, S.F. Inequality Matters; William T Grand Foundation: NewYork, NY, USA, $2014 ;$ p. 23.

51. Ceddia, G.M. The impact of income, land, and wealth inequality on agricultural expansion in Latin America. Proc. Natl. Acad. Sci. USA 2019, 116, 2527-2532. [CrossRef] [PubMed]

52. International Monetary Fund. Dimensions of Land Inequality and Economic Development Prepared by Lennart Erickson and Dietrich Vollrath; International Monetary Fund: Washington, DC, USA, 2004; p. 24.

53. Guerena, A.; Wegerif, M. Land Inequality Framing Document; International Land Coalition: Rome, Italy, 2019; 92p.

54. World Bank. 2021. Available online: https:// data.worldbank.org/indicator/SL.AGR.EMPL.FE.ZS (accessed on 22 May 2021).

55. FAO. Available online: http:/ / www.fao.org/3/i5488e/i5488e.pdf (accessed on 28 May 2021).

56. FAO. 1998. Available online: http://www.fao.org/3/i2050e/i2050e02.pdf (accessed on 28 May 2021).

57. Patil, B.; Babus, V.S. Role of women in agriculture. Int. J. Appl. Res. 2018, 4, 109-114.

58. FAO. World Census of Agriculture: Analysis and International Comparison of the Results (1996-2005); FAO Statistical Development Series 13; FAO: Rome, Italy, 2011.

59. Agricultural Cenus. Available online: http:/ /agcensus.dacnet.nic.in/ (accessed on 15 January 2020).

60. GOI. Agricultural Statistics at a Glance 2018; Government of India Ministry of Agriculture \& Farmers Welfare Department of Agriculture, Cooperation \& Farmers Welfare Directorate of Economics and Statistics: New Delhi, India, 2019; 502p.

61. USDA. 2021. Available online: https://www.ers.usda.gov/data-products/chart-gallery/gallery/chart-detail/?chartId=58268 (accessed on 15 June 2021).

62. IASRI. Agricultural Research Data Book; Indian Agricultural Statistics Research Institute: New Delhi, India, 2019; 366p.

63. India budget. Available online: https:/ / www.indiabudget.gov.in/budget2016-2017/survey.asap (accessed on 22 September 2019).

64. Census of India. Available online: http://censusindia.gov.in/2011-prov-results/data_files/india/Final_PPT_2011chapter7.pdf (accessed on 18 June 2021).

65. Subramanian, S. Emerging Trends and Patterns of India's Agricultural Workforce: Evidence from the Census; The Institute of Social and Economic Change: Bengaluru, India, 2015; 21p, ISBN 978-81-7791-203-6.

66. Srivatsava, S.K.; Singh, J.; Kumar, N.R.; Singh, N.P.; Ahmad, N. Changing agricultural Labour market and its effects on farm economy in India. Indian J. Agric. Econ. 2020, 75, 469-480.

67. FAO. Farms, family farms, farmland distribution, and farm labour: What do we know today? ESA Work. Pap. $2019,19,80$.

68. NSSO. Key indicators of situation of agricultural households in India. In National Sample Survey 70th Round; Government of India, Ministry of Statistics and Programme Implementation, National Sample Survey Office: New Delhi, India, 2013; p. 123. Available online: http://mospi.nic.in/sites/default/files/publication_reports/KI_70_33_19dec14.pdf (accessed on 6 April 2021).

69. Deininger, K.; Jin, S.; Hari, K.N. Efficiency and Equity Impacts of Rural Land Rental Restrictions: Evidence from India; World Bank: Washington, DC, USA, 2007. Available online: https:/ / elibrary.worldbank.org/doi/citedby/10.1596/1813-9450-4324 (accessed on 18 May 2021).

70. FAO. Land tenure and rural development. In FAO Land Tenure Studies; FAO: Rome, Italy, 2002.

71. Bandyopadhyay, D. Land reforms and agriculture: The West Bengal experience. Econ. Political Wkly. 2003, 38, 879-884. Available online: https:/ / www.jstor.org/stable/4413274 (accessed on 15 April 2021).

72. Bardhan, P.; Luca, M.; Mookherjee, D.; Pino, F. Evolution of land distribution in West Bengal 1967-2004: Role of land reform and demographic changes. J. Dev. Econ. 2014, 110, 171-190. [CrossRef]

73. OECD. 2001. Available online: https://www.oecd.org/greengrowth/sustainable-agriculture/2739771.pdf (accessed on 21 April 2021).

74. Morris, W.; Dowella, D. Farm diversification, entrepreneurship and technology adoption: Analysis of upland farmers in Wales. J. Rural Stud. 2017, 53, 132-143. [CrossRef]

75. Nithya, N.R. Land question and the tribals of Kerala. Int. J. Sci. Technol. Res. 2013, 2, 102-105.

76. Mohanty, B.B. Land distribution among scheduled castes and tribes. Econ. Political Wkly. 2001, 36, 3857-3868.

77. Agarwal, B. Gender and command over property: A critical gap in economic analysis and policy in South Asia. World Dev. 1994, 22, 1455-1478. [CrossRef]

78. Cepal, N.U. Estrategia de Montevideo para la Implementation de la Agenda Regional de Género en el; The United Nations: New York, NY, USA, 2016.

79. World Bank. Land Reform Sector Policy Paper; World Bank: Washington, DC, USA, 1975.

80. Terresdeurope. Available online: http:/ / www.terresdeurope.net/en/france-agriculture-leading-country-europe.asp (accessed on 15 May 2021).

81. Singh, S.; Toor, M.S. Agrarian crisis with special reference to indebtedness among Punjab farmers. Indian J. Agric. Econ. 2005, 60, 335-346.

82. Mythili, G.; Goedecke, J. Economics of land degradation in India. In Economics of Land Degradation and Improvement-A Global Assessment for Sustainable Development; Nkonya, E., Mirzabaev, A., Braun, J., Eds.; Springer: Berlin, Germany, 2019 ; pp. $431-469$. 
83. FAO. Land Degradation in South Asia: Its Severity Causes and Effects upon the People; Food and Agriculture Organization: Rome, Italy, 1994. Available online: http:/ / www.fao.org (accessed on 15 March 2021).

84. Kumar, S.; Meena, P.C.; Shakti, R.P. Changing dynamics of tenant farming in India-An insight from Gujarat. Indian J. Econ. Dev. 2017, 13, 65-70. [CrossRef]

85. Mani, G. Model agricultural land leasing act, 2016: Some observations. Econ. Political Wkly. 2016, 51, 42. Available online: https: //www.epw.in/journal/2016/42/web-exclusives/model-agricultural-land-leasing-act-2016-some-observations.html (accessed on 19 June 2021).

86. Athreya, V.B.; Djurfeldt, G.; Lindberg, S. Barriers Broken. Production Relations and Agrarian Change in South India; SAGE Publications: Thousand Oaks, CA, USA, 1990; 335p. 